\title{
Syn-kinematic sedimentary systems as constraints on the structural response of thrust belts: re-examining the structural style of the Maghrebian thrust belt of Eastern Sicily
}

\author{
Robert W.H. Butler (1), Rosanna Maniscalco (2) \& Patricia R. Pinter (3)
}

\section{ABSTRACT}

Structural evolution of thrust wedges is influenced by synkinematic deposition ahead and upon them. It dampens uplift of synclines and promotes amplification of anticlines. High-resolution marine seismic images and analogue experiments indicate that emergent thrusts only form upper thrust flats (detachments, required to form far-travelled tectonic allochthons) when depositional rates at the thrust front are very low. These interactions are illustrated by re-examining tectonostratigraphic evolution of the Neogene eastern Sicily, a rotational thrust belt forming part of the Maghrebian orogen of the central Mediterranean. Existing interpretations of the thrust belt which invoke stacking of far-travelled thrust sheets (e.g. the "Sicilide") are incompatible with stratigraphic data that are better explained by deposition upon a simple emergent imbricate fan. The distribution of pre-kinematic successions reflects basin-structuring before Neogene thrusting, so that Mesozoic depositional units are unreliable guides for structural interpretation and associated palinspastic restoration. Deformation in the thrust wedge is marked by spaced anticlines that amplify together in an array, with individual structures active for at least 6 million years. The shortening across individual structures in the thrust wedge is rather low (a few $\mathrm{km}$ ). Yet, reconstructing the palaeomagnetic rotation history of the thrust wedge requires $>200 \mathrm{~km}$ displacement, which must have chiefly localised on the basal detachment. This behaviour was strongly facilitated by the synkinematic thrust front remaining sediment-starved for much of its history. In contrast, during much of the Mio-Pliocene, sedimentation was ponded on top of the thrust wedge. In eastern Sicily, only in the Pleistocene, and briefly during the Tortonian, did significant sedimentation occur at the thrust front and this temporarily changed thrust localisation. Displacement partitioning reflects this inferred distribution of syn-kinematic deposition. Characterising these interactions is important for interpreting the structural style in thrust systems, especially when assessing the role of allochthonous thrust sheets.

KEY WORDS: tectono-stratigraphy, thrust geometry, palaeogeographic reconstruction, Neogene.

\section{INTRODUCTION}

Structural interpretation of continental thrust systems is inherently uncertain. Even in settings with numerous well-penetrations and seismic reflection data acquired and processed to high industry standards, subsurface interpretations commonly fail when tested by further

(1) Fold-thrust Research Group, School of Geosciences, University of Aberdeen, Aberdeen AB24 3UE, United Kingdom.

(2) Department of Biological, Geological and Environmental Sciences, University of Catania, Corso Italia, 57, 95129 Catania, Italy.

(3) School of Geosciences, University of Aberdeen, Aberdeen AB24 3UE, United Kingdom (present address: CGG Robertson, Tyn-ycoed, Llandudno LL30 1SA, United Kingdom).

Corresponding author e-mail: rob.butler@abdn.ac.uk drilling (reviewed by ButLer et alii, 2018). Indeed, seismic reflection data can yield entirely misleading images as a consequence of spatially complex heterogeneous seismic velocity and correspondingly tortuous ray-paths. Consequently, maps of surface geology remain important sources of data from which structure can be projected to depth. However, challenges arise in subsurface interpretation when structures are disharmonic, separated by multiple detachments. The approach developed here arises from the recognition that emergent thrust systems are geometrically distinctive from buried systems (Fig. 1). In buried thrust systems, imbricate thrusts can recombine up-dip to form duplexes (e.g. Boyer \& ElliotT, 1982). Yet when thrusts climb to the syn-orogenic surface they can become progressively over-stepped by syn-kinematic sediments. Not only do these sediments provide key information on the growth of structures, they can also influence the trajectories of faults and thus the geometry of the thrust wedge (e.g. STORTI \& McClaY, 1995). The aim of this paper is to examine structural evolution in the Maghrebian thrust system of central-eastern Sicily, a setting with unrivalled syn-kinematic successions and existing structural interpretations that, as discussed below, are becoming increasingly untenable in the light of new geological data. This paper necessarily discusses regional geology and, while attempting to be concise, unavoidably focusses on specific structural-stratigraphic relationships that are primarily relevant to Sicilian geology. Brief introductory notes are provided below. Some of the more generic observations and deductions are developed in a companion paper (BuTLER, in review), which has examples from the Himalayas and Apennines.

\section{EMERGENT VS BURIED THRUST SYSTEMS}

Many of the basic geometric elements of thrust belts were developed from preserved parts of ancient systems such as the Appalachians and Moine Thrust Belt (e.g. Hatcher, 1978; Elliott \& Johnson, 1980) that did not directly interact with their syn-orogenic surface. It is these locations that provide type-examples of duplexes and related structures: thrust sheets formed at depth, wellbelow the syn-orogenic surface. They are entirely enclosed by thrust surfaces (e.g. BOYER \& ELLIOTT, 1982; ButLER, 1987; Fig. 1) and are therefore said to be "buried". In contrast, "emergent" thrust systems are represented by imbricate fans and related folds that influence accumulation of synkinematic sedimentation and associated local erosion (e.g. 
Williams, 1993). On restored sections, emergent thrust systems have segments of syn-kinematic sedimentation displayed on their restored templates (Fig. 1b), the bedlengths of which decrease up-section in response to the gradual accumulation of shortening. Restored sections for buried thrust systems cannot show syn-kinematic deposits because the thrust slices were stacked entirely in the subsurface (Fig. 1c).

A variety of approaches reveal fundamental differences in the structure of buried thrust systems in comparison with those that develop into strata that accumulated during deformation (Fig. 2). Many analogue experiments have explored the large-scale dynamics of thrust wedges and a few examine the role of sedimentation on the trajectories of individual thrusts. STORTI \& MCCLAY (1995) show thrusts that form without syn-kinematic sedimentation climb section and then follow upper detachments (thrust flats). The resultant thrust wedge structure is marked by closelyspaced faults (Fig. 2a). At large displacements these types of thrusts can recombine up-dip to entirely isolate thrust slices, forming duplexes (in the manner and sense of BOYER \& ElLIOTT, 1982). In contrast, when there is syn-kinematic sedimentation the imbricate thrusts continue to climb ramps into the growth strata. Upper thrust detachments are not activated. The resultant thrust wedge comprises an array of widely spaced anticlines separated by synclines within which thrust-top sediments are ponded. The generality of the results of STORTI \& McCLAY (1995) have since been repeatedly reproduced (e.g. Bonnet et alii, 2008; GRAVELEAU et alii, 2012).

Insights on natural relationships between strata and deformation are best gained from marine seismic reflection data. Compared with their continental counterparts, seismic velocity structure is generally much less complex, seismic energy penetration is excellent, static corrections are less limiting and acquisition is far simpler so that seismic imaging is unparalleled in marine settings (e.g. Higgins et alii, 2009; ButLer \& Paton, 2010;
Totake et alii, 2018). Therefore, they offer exceptional images of structures and their relationship to stratigraphy. Consider an example from the deep-water fold-thrust belt of the outer Niger Delta (Fig. 2c-e). In this structure, the forelimb of a thrust-associated anticline is cut by an array of thrusts. Stratal reflectors continuous with an unfaulted stratigraphic section ahead of the fold onlap faulted strata in the forelimb. However, faults shallower in the section cut deeper stratal reflectors but are themselves overstepped by younger ones. Thus, the thrust splays repeatedly climb section but cease displacement, to be replaced by younger fault strands progressively developed in their hangingwalls. Syn-kinematic sedimentation inhibits the activation of upper thrust detachments. This type of behaviour is directly analogous to salt-canopies climbing ramps as a form of progressive unconformity, in halokinetic systems (e.g. Hudec \& JACKSON, 2009). Syn-kinematic sedimentation at the thrust front forces this thrust to climb a ramp.

Insights from analogue experiments and numerous high-quality seismic images from deepwater thrust belts indicate that syn-kinematic sedimentation exerts a primary control on thrust geometry. Therefore, emergent thrusts systems are expected to develop in a distinctly different fashion to buried systems. Simple application of duplex models with upper thrust detachments would appear unwarranted for thrust belts that hosted significant syn-kinematic sedimentation. These are the deductions that inspire a re-examination of thrust system evolution in the Maghrebian thrust belt of Sicily, building on our longstanding studies of syn-kinematic deposition.

\section{SICILY: TECTONOSTRATIGRAPHIC NOTES}

Before applying the insights from emergent thrust systems, it is necessary to introduce aspects of the tectonic geology of Sicily with specific reference to emergent imbricate fan

a)

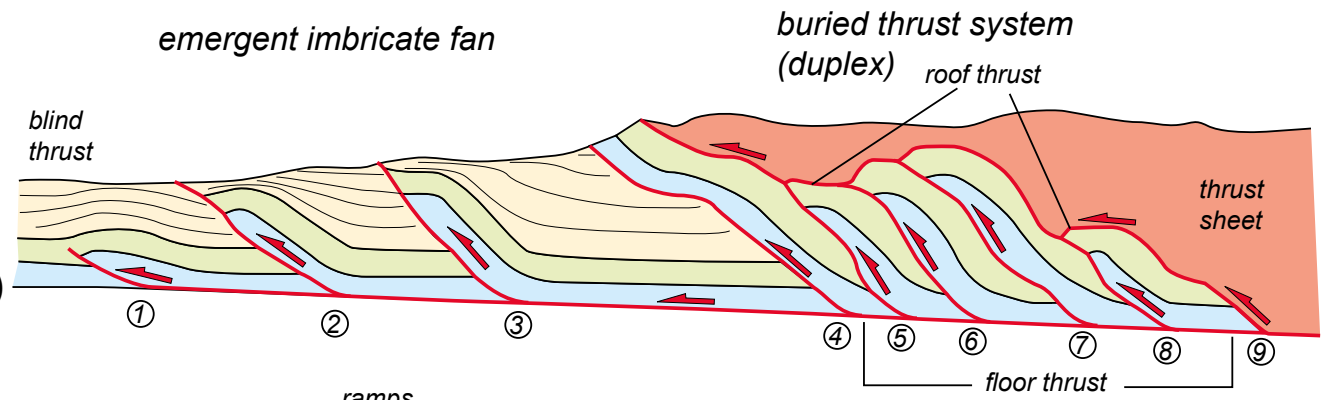

b)

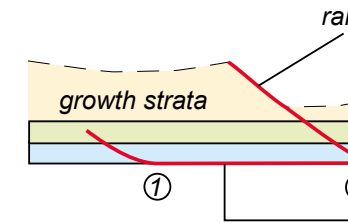

c)

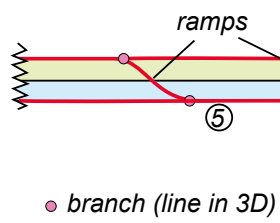

growth strata
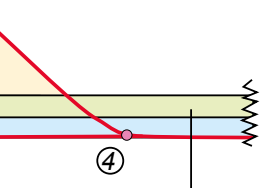

pre-kinematic strata

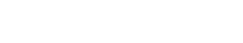

basal detachment (floor)
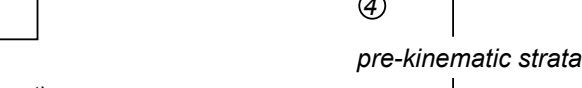

Fig. 1 - The distinction between emergent and buried thrust systems (modified after ButLer, 2004). a) illustrates a hypothetical cross-section. Thrusts are numbered for cross-reference to the restored sections ( $b$ and $c$ ) and do not imply a sequence of activity. The emergent thrusts (1-4) climb stratigraphic section from pre-kinematic strata (blue, green) into the synkinematic ("growth") strata $(\tan )$, defining continuous ramps. In contrast, the buried thrust system (5-9) are marked by entirely fault-bounded thrust slices. The imbricate thrusts recombine up dip onto a single roof thrust that forms a bed-parallel upper detachment ("flat") along the top of the green, pre-kinematic layer. 


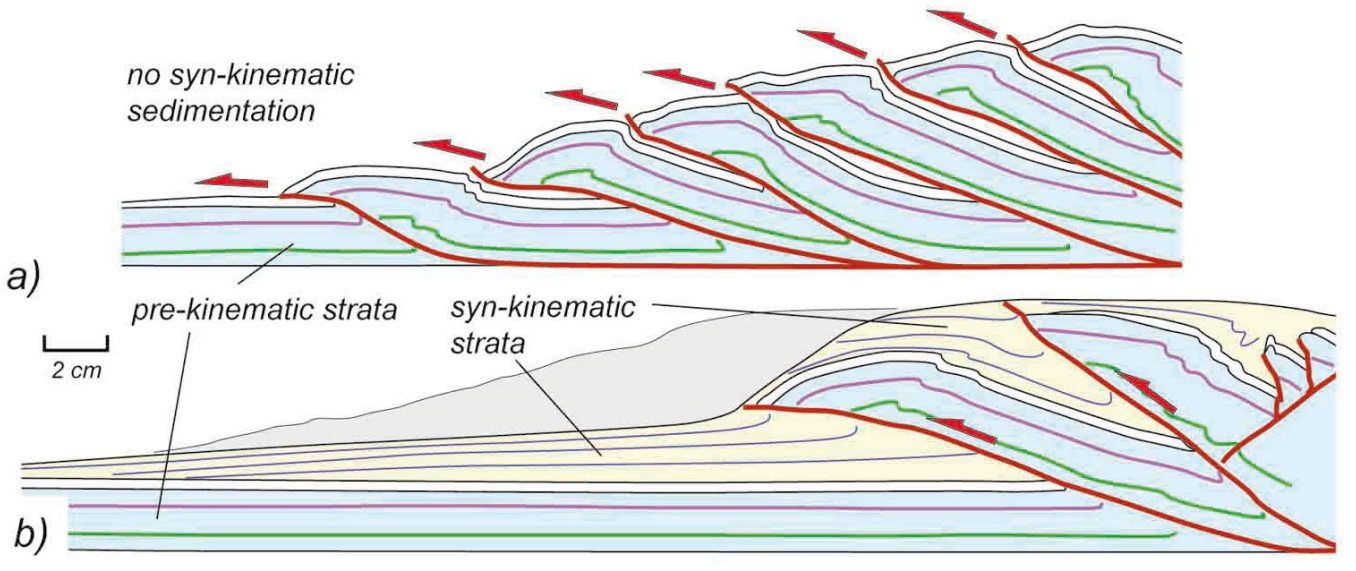

c)
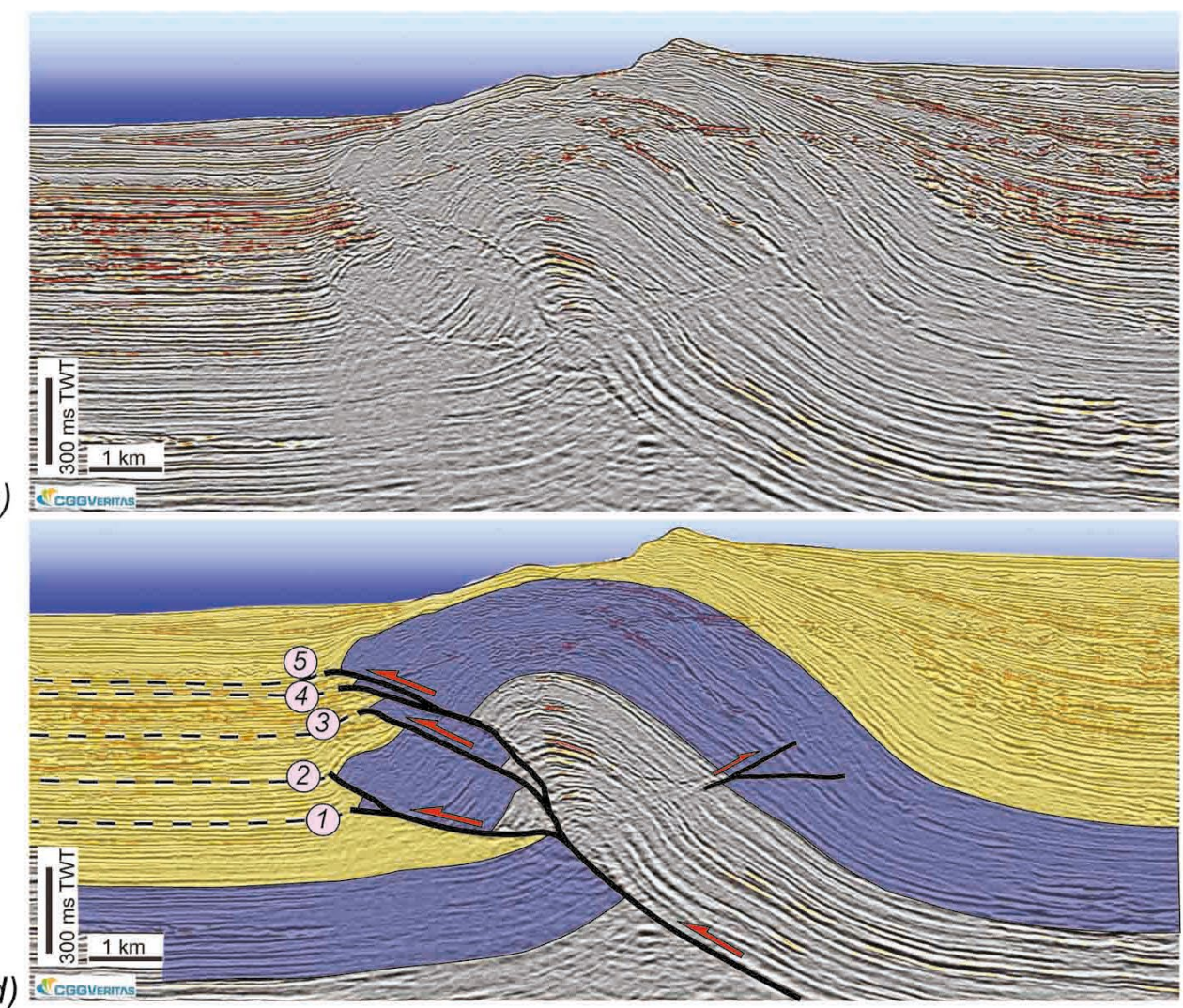

d)

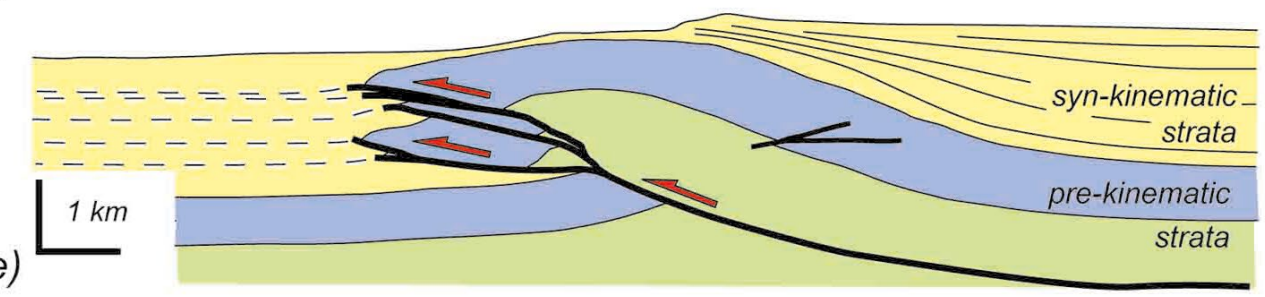

Fig. 2 - A comparison between results from analogue experiment of thrusts $(a, b$; after STORTI \& MCCLAY, 1995) with a seismic section (c-e) from the deep-water thrust system of the outer Niger Delta (seismic image courtesy of CGG (formerly CGG Veritas) and the Virtual Seismic Atlas.) a) illustrates imbrication with no syn-kinematic sedimentation so that thrust slices are closely spaced and their thrusts climb up onto the upper flat. b) illustrates thrusting with synkinematic sedimentation. Here the thrusts climb continuous ramps, without upper flats. The thrust slices are correspondingly more widely separated than in (a). the Maghrebian thrust system. The island occupies a pivotal position in the tectonic framework of the Central Mediterranean (e.g. Catalano et alii, 1996; Fig. 3). Much of the island comprises deformed Tertiary and other sedimentary successions that are generally accepted to be allochthonous and constitute the eastern continuation to the Maghrebian orogen of northern Africa (see Grasso, 2001, Elter et alii, 2013; and references therein for review). Adjacent to these displaced units, in the SE of the island, the Hyblean plateau (Fig. 3) represents the orogenic foreland (e.g. Burollet et alii, 1977), an outcropping extremity of the African continent. Through the Tertiary there has only been minor faulting in this "Pelagian" foreland area, weak deformation that is recognized through the offshore and in the North African mainland (Grasso et alii, 1990). 
The orogenic hinterland is represented by "Calabrian" basement, vestigial portions of which crop out in the Peloritani Mountains of NE Sicily (e.g. LENTINI, 1982; Fig. 3) and is generally inferred to be submerged beneath the southern Tyrrhenian Sea (e.g. Catalano et alii, 2013). Cretaceous turbidites (Monte Soro Flysch) and various olistostromal units lie along the southern border of the Calabrian units, generally interpreted to be pre-collisional "trench" deposits (see reviews by Grasso, 2001). The Maghrebian thrust system is developed between Calabrian and Pelagian domains and at outcrop exclusively comprises Mesozoic-Cenozoic sedimentary successions. Allochthoneity of these successions is established through penetrations by wells including Ramacca 1 (BIANCHI et alii, 1989) and Settafarine (e.g. LicKorish et alii, 1999; Fig. 3). These traverse older Miocene rocks lying upon Pliocene units that in turn lie unconformably upon carbonates of the Hyblean foreland.

Thrusting is generally inferred to have been "Africadirected" with tectonic rotations (up to 100 degrees CW) in Mesozoic strata with respect to Hyblea (reviewed by CIFELLI et alii, 2007 and, for western Sicily, by SPERANZA et alii, 2018). These rotations progressively reduce in younger strata, consistent with rotational overthrusting through the
Neogene. In recent years various groups have proposed that these rotations are diagnostic of significant right-lateral, east-west-trending strike-slip tectonics (e.g. CATALANo et alii, 2018). However, more detailed palaeomagnetic work suggests otherwise: strike-slip systems through most of eastern Sicily have only very minor offsets (SPERANZA et alii, 2018). As major stratigraphic boundaries of the syn-kinematic successions are not significantly displaced by strike-slip faults within the thrust belt, we consider this deformation mode to be of only local significance, probably forming in response to local heterogeneities in fold-thrust amplification and acting as local compartmental structures which are common in all thrust systems. The regional tectonics is best described as a zone of rotational overthrusting.

\section{SYN-KINEMATIC STRATA OF THE EAST-CENTRAL THRUST BELT}

As Granath \& CASERo (2004) amongst others report, all outcropping tectonostratigraphic units in the eastern Sicilian thrust belt are overlain by synorogenic successions, starting with the lower Miocene Numidian successions. The depocenter for these Neogene successions is generally termed the Caltanissetta Basin (e.g. Decima \& Wezel, 1973; Fig. 3), a misnomer because

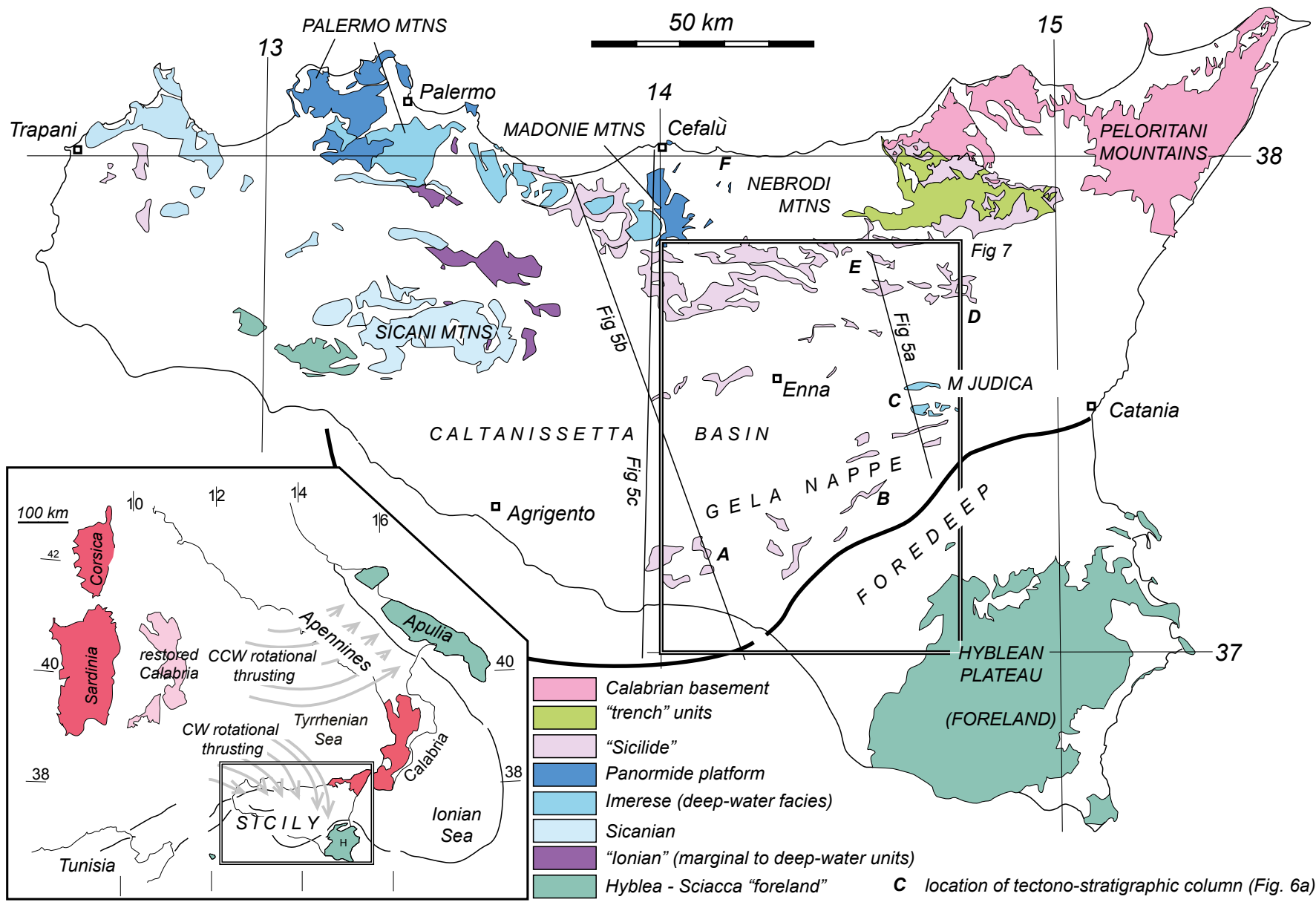

Fig. 3 - Simplified map of the Maghrebian thrust belt of Sicily (inset location map) showing the distribution of pre-kinematic strata. Syn and post-kinematic strata are unornamented. The boxed area is the map area of Fig. 7. Map modified after Carbone \& Lentini (2013). The lines of cross-sections (from Fig. 5) are cropped in the foreland (for precise extents see original publications: CARBONE et alii, 1990; CATALANO et alii, 2013; LENTINI et alii, 1996 respectively). 
it is not one single depocenter but comprises arrays of synclines developed above the tectonised sedimentary successions of the thrust belt (e.g. BUTLER \& LicKORISH, 1997). Simplified composite stratigraphic columns for Neogene strata for the "basin" are presented here (Fig. 4). Extensive stratigraphic notes and the summaries of the sedimentary response to deformation are presented in the literature cited below. The strata are described from topdown.

The succession is capped by a subaerial surface charting the uplift of Sicily, presumably due to tectonic unloading in the orogenic hinterland. It shows over $1 \mathrm{~km}$ of differential relief, inclined southwards to the modern coast line and, as expected of a forced regression, formed diachronously from the late Pliocene onwards (BUTLER et alii, 1995a). The surface represents the top of a generally shallowing-upwards succession of marine strata that began to accumulate from the start of the Pliocene. External siliciclastic input was very limited - most of the sediment is biogenic. The top of the succession is represented by near-shore palaeoenvironments defined by parasequences with broadly southward migrating clinoforms built from packstones (e.g. LicKORISH \& BUTLER 1996; ButLer et alii, 1995a). The base of the succession is characterised by the Trubi Formation, precession-

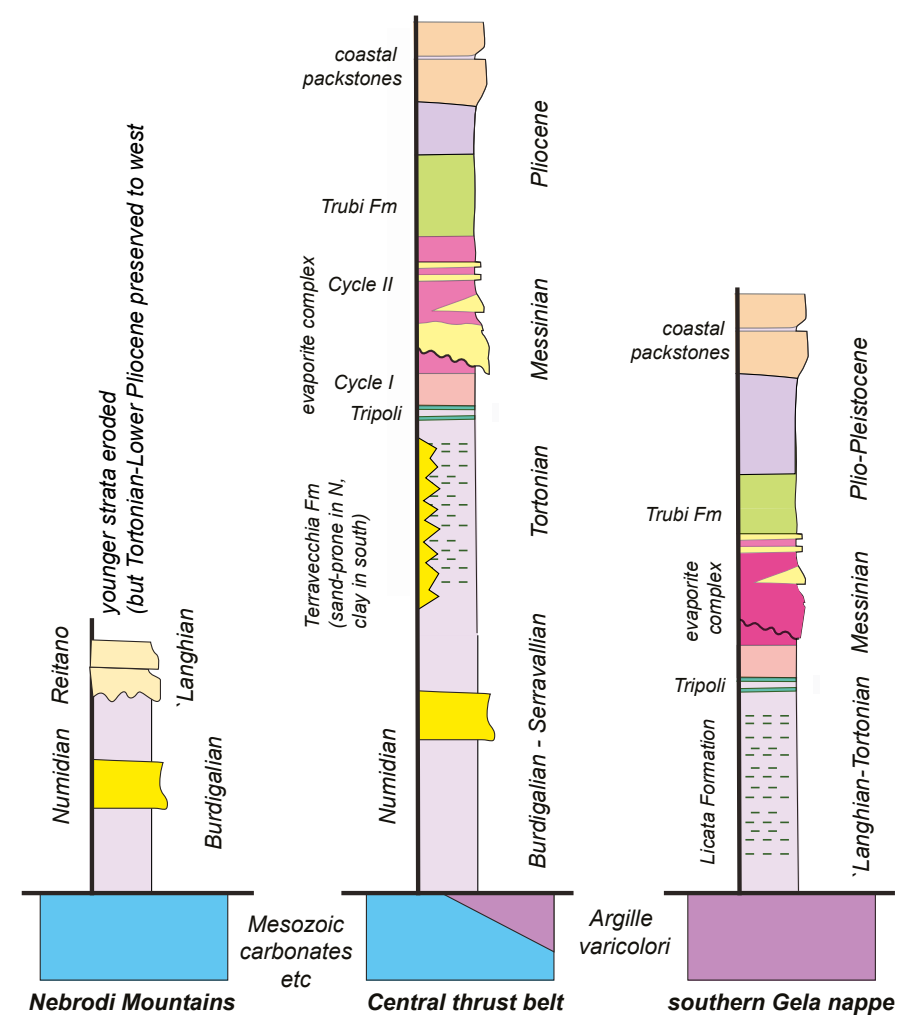

Fig. 4 - Simplified representative vertical sections for the synkinematic strata of eastern Sicily. The sections are unscaled because the stratigraphies vary from basin to basin and across anticlines. The Numidian succession can achieve thicknesses of $2-3 \mathrm{~km}$, the Terravecchia Formation can exceed a km based on outcrop, and may locally exceed $2 \mathrm{~km}$ in wells. The Messinian evaporites achieve thicknesses of up to $1 \mathrm{~km}$ in some synclines and the Pliocene succession can achieve similar values across the thrust belt. cyclically deposited chalks (VAN Couvering et alii, 2000). The chalks record very little detrital input, and pass up into marls and carbonate mudstones that represent the offshore continuation of the advancing packstone coast line.

Messinian strata include important evaporitic successions (the Gessoso Solfifera Formation of OGNIBEN, 1957) that show rapid variations in facies and thickness in and out of synclines across the thrust belt (BuTLER et alii, 1995b; 2015), although more southern parts of the system are marked by a regional blanket of rhythmically autobrecciated carbonates - the Calcare di Base of DEcIMA \& Wezel (1973). Messinian evaporites are divided into two "mega-cycles", separated by a subaerial unconformity which presumably correlates with a low-stand in the Mediterranean water body (ButLER et alii, 1995b).

In basinal settings the Messinian evaporites or their correlative carbonates pass up from diatomaceous laminites of the Tripoli Formation which contain the palaeobiological harbingers of the "salinity crisis" (e.g. Pedley \& Maniscalco, 1999). On the flanks and crests of anticlines, the Calcare di Base passes up from the Terravecchia Formation (GRAsso \& PEDLeY, 1988). This is a terrigenous succession which is mudstone dominated in the south but includes shallow-marine and aerial sandstones and conglomerates in the north. The southern limit of sandstone deposition and sediment pathways, recorded by the coarse clastics, coincide with folds (JonES \& Grasso, 1997). The Terravecchia also contains patchreefs that built on anticline crests (GRAsso \& Pedley, 1988). Collectively both the Terravecchia and Tripoli Formations straddle the Tortonian-Messinian boundary and are interpreted to be lateral equivalents, charting the different degrees of isolation, clastic ingress and water chemistry across the bathymetrically complex top of the thrust wedge (e.g. Pedley \& Maniscalco, 1999).

Shallow-marine - subaerial sandstones of Serravallian to Early Tortonian age unconformably overlie deformed substrate in the northern part of the Caltanissetta Basin, south of the Madonie mountains (Fig. 3). They are shallow-marine, continental deposits of the Castellana Sicula Formation (Catalano \& D'Argenio, 1990). Deeper marine Serravallian successions are reported for various locations beneath Tortonian clays elsewhere in the Caltanissetta Basin but are generally included within the lithostratigraphic Terravecchia Formation.

Lower Miocene syn-kinematic strata are represented by turbidite sandstones and associated mudstones, broadly constituting the Numidian system. Significant sand input, now broadly accepted as being derived from the African foreland and delivered laterally along the thrust belt (see PINTER et alii, 2016; 2018 for discussion) reached the thrust system of east-central Sicily in the AquitanianBurdigalian. This sand fairway appears to have migrated southwards (in the modern reference frame, eastwards when corrected for tectonic rotations) into the Langhian. Deep-water quartz sandstones and clays continue up into the Serravallian in the Monte Judica area (CARBONE et alii, 1990; Fig. 3). More northern parts of the thrust belt were eroded and overlain by orogen-sourced turbidites of the Reitano Formation, also of Langhian age (GRAsso et alii, 1999).

In the southern part of the Caltanissetta Basin the pre-evaporitic strata are represented by rhythmically- 
deposited claystones of Licata Formation (GRAsso et alii, 1997) together with a veneer of Tripoli Formation. The Licata Formation straddles the Langhian to late Tortonian and is therefore the lateral equivalent of the highly differentiated pre-evaporitic syn-kinematic strata of the northern Caltanissetta Basin. It rests on variegated clays of early Miocene age. Apart from showing significant variations in stratigraphic thickness (GRAsso et alii, 1997; LICKORISH et alii, 1999) it is difficult to establish how much of the Licata Formation is pre or syn-kinematic with respect to local thrusts and folds. It is clear however that clastic input was very limited, with no significant sandgrade clasts being transported to this part of the basin.

\section{EXISTING CROSS-SECTION INTERPRETATIONS}

There are numerous competing published versions of cross-sections across the Sicilian thrust belt, some of which rely on heritage seismic reflection data (e.g. BELLO et alii, 2000; Avellone et alii, 2010; Albanese \& Sulli, 2012). A selection of regional interpretations for eastern Sicily is reproduced here to illustrate key points in existing interpretations (Fig. 5). Most show large-scale displacements on stacked flat-lying detachments that juxtapose originally far-separated rock units. CARBONE et alii (1990; after BIANCHI et alii, 1989) propose that the structure beneath the vestigial thrust-top basin at Centuripe is underlain by repeated slices of the early syn-kinematic strata - the Numidian turbidites.

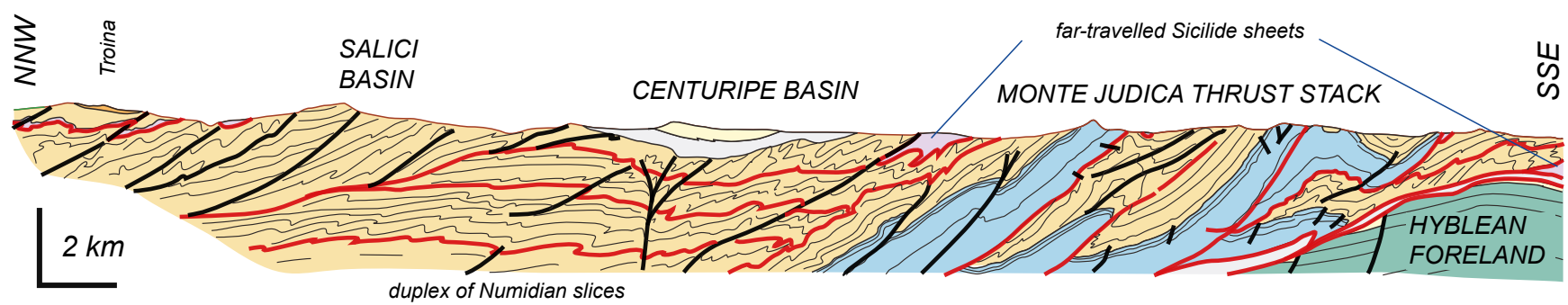

a)
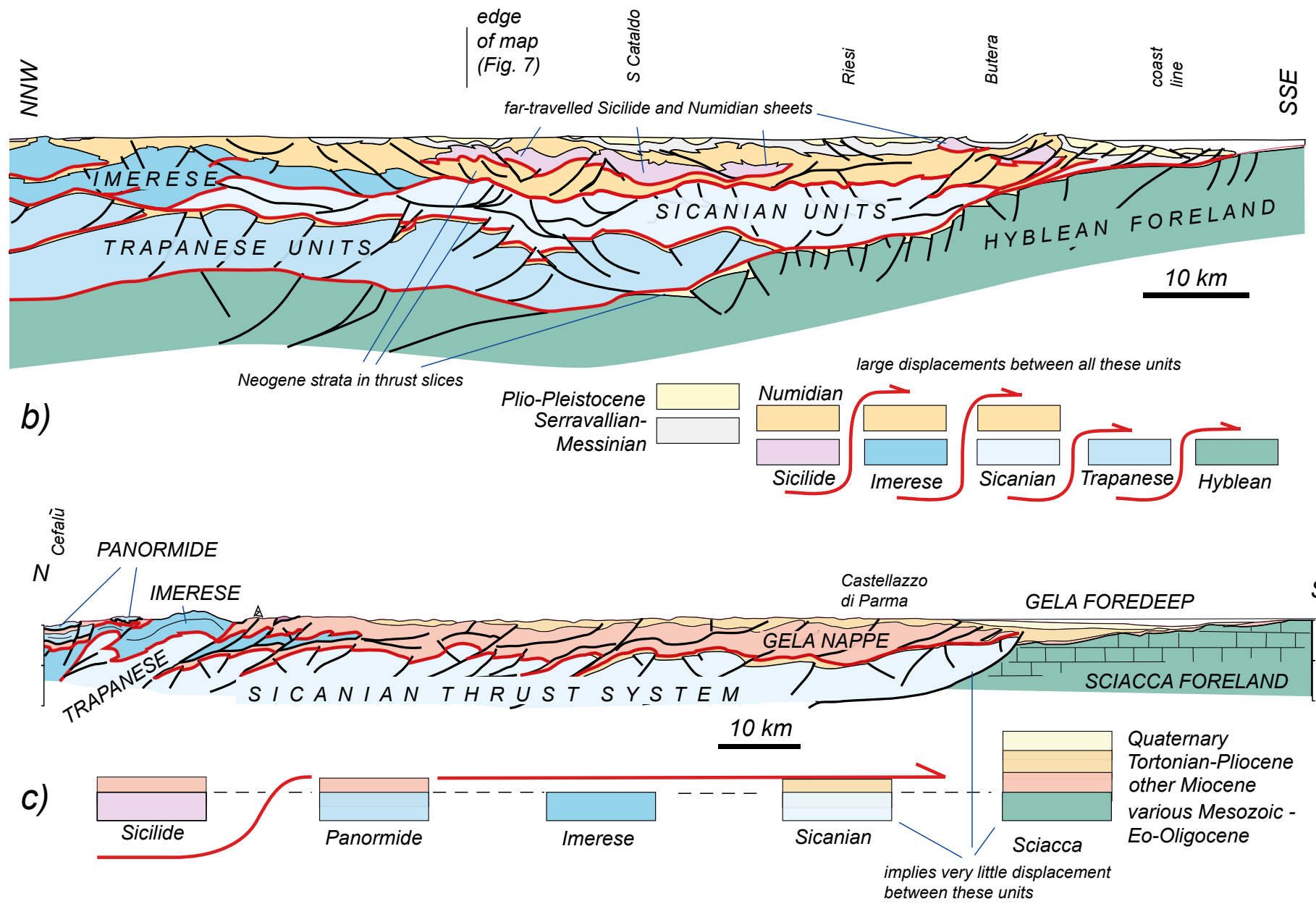

Fig. 5 - Selected published cross-sections through parts of the Maghrebian thrust system on Sicily, labelled here to highlight specific features. a) CARBOnE et alii (1990) through part of the eastern thrust belt. b) CATALANO et alii (2013) along the line of the SiRiPRO seismic reflection profile. c) LENTINI et alii (1996), approximately along the SiRiPRO transect but constructed before its acquisition. 
Their interpretation (Fig. 5a) assumes that distinct facies in these turbidites must have been deposited in widely separated locations and that their present juxtaposition reflects substantial tectonic translations (e.g. GUERRERA et alii, 2012). In this interpretation, the structure is that of a largescale duplex. This explanation for the modern distribution of facies within the Numidian system has been challenged by PINTER et alii $(2016,2018)$. They show that facies vary over distances of a few $\mathrm{km}$ as a consequence of deposition in relatively narrow, structurally confined corridors rather than across a broad fan on an unconfined basin floor. Thus, large-scale thrust juxtaposition is not required to explain the present distribution of facies within the Numidian turbidites. Indeed, in many sites (e.g. within the Salici Basin (Fig. 5a), Pinter et alii, 2018), depositional architectures can be traced directly across areas previously interpreted as containing thrusts (c.f. CARBONE et alii, 1990). We discuss a re-interpretation of this profile (Fig. 5a) later in this paper.

Duplex stacking is also adopted as a structural style by Catalano et alii (2013) in their interpretation of the SiRiPRO seismic reflection profile. They propose that the thrust belt is formed by three distinct far-travelled thrust sheets (Fig. 5b) that comprise distinctive Mesozoic tectono-stratigraphic units. Each of these units is shown to include a succession of Numidian strata so that the structures are defined by two distinct detachment horizons (thrust "flats"), a lower one at the base of the Mesozoic strata, and an upper one within the Lower Miocene. This interpretation also places a panel of carbonates at depth, a proposition that the entire thrust belt onshore Sicily is underlain by the Hyblean foreland.

An alternative version (Fig. 5c), broadly along the section line of CATALANO et alii (2013) is proposed by LENTINI et alii (1996), well-before the acquisition of the SiRiPRO seismic profile. Rather than show platform units of the Hyblean foreland continuing beneath the more internal (northern) thrust belt, they show a thrust ramp across which are juxtaposed more basinal carbonates (Sicanian units) against the Hyblean platform. Thus, the deep structure of the thrust belt is marked by imbricated "foreland" and the thrust belt is carried on a single detachment. Although this model appears simply to be a fore-runner of that of CATALANO et alii (2013), LENTINI et alii's (1996) interpretation does not show the buried thrust slices involving syn-kinematic (Neogene) strata. This is an important distinction, as evident below. Nevertheless, both Lentini et alii (1996) and CATALANo et alii (2013) use the constituent Mesozoic facies to schematically restore the thrust system.

\section{The SicILIDE PROBLEM}

Assumptions of the palaeogeographic arrangement of distinct tectono-stratigraphic successions underpin most regional studies of the structure of the Maghrebian thrust system of Sicily, such as that shown in Fig. 5b. In essence, the units are defined by distinctive Mesozoic rock sequences that imply distinct palaeobathymetric evolutions, used to infer relative positions across an ancestral continental margin. Building on Argand's original Alpine interpretations, OGNIBEN (1960) applied palaeogeographic configurations to Sicily and the scheme was formalised by CATALANO \& D'ARgENIO (1978) amongst others. These configurations continue to provide firstorder constraints on regional structural models, including making precise interpretations of the Mesozoic facies contained within subsurface thrust sheets deduced from seismic reflection profiles (e.g. Catalano et alii, 2013) and in placing thrusts on maps and cross-sections (Fig. 5). The present-day distribution of the various tectonostratigraphic units is shown on Fig 3, following the terminology of LENTINI \& CARBONE (2014). The foreland area is represented by platforms that crop out as the Hyblean plateau in SE Sicily. Within the thrust system much of the Mesozoic succession is in deep-water facies and constitutes the Imerese and Sicanian units. Mesozoic platform units are found within the thrust system, designated Trapanese and Panormide for outcrops in NW Sicily and in the Madonie mountains respectively. A final unit, which occupies pivotal positions in structural restorations, is inferred to form an upper far-travelled thrust sheet derived from a strongly subsided, deep-water location. This is the Sicilide unit, chiefly comprising red scaley clays, marls and thin carbonates collectively termed "Argille Varicolori". These are late Cretaceous to Oligocene in age and are generally interpreted to have detached from their older substrate (e.g. OGNIBEN 1960 and numerous authors thereafter). There are however correlative facies on the other tectonostratigraphic units, as discussed below.

All interpretations of thrust belt structure illustrated on Fig. 5 show the Sicilide to be a far-travelled thrust sheet that lies structurally across all other tectonic units. Argille Varicolori, inferred to lie within a Sicilide sheet, are found in the far-south of the thrust system, near the front of the "Gela Nappe" (location E on Fig. 3) as well as throughout central-eastern Sicily. By considering it to represent an upper thrust sheet (e.g. CATALANO \& D'ARGENIO, 1978; BiAnchi et alii, 1989; Catalano et alii, 2013 and many others), the Sicilide is required to have been emplaced over inliers of Mesozoic units in the Madonie mountains.

We concur with Avellone et alii (2010) that all Mesozoiclower Tertiary stratigraphic units within the Maghrebian chain are overlain by strata of up to Burdigalian age. It is the stratigraphic relationships of these and other Miocene strata that falsify the notion that the Sicilide (Argille Varicolori) represents a far-travelled thrust sheet that is derived from locations further oceanward than other Mesozoic successions (e.g. Panormide, Imerese etc) now stacked together in the Sicilian thrust belt. We summarise these relationships on Fig. 6a (with locations cross-referenced on Fig 3). In the southern part of the thrust belt (location A on Fig. 6a), represented by the Gela Nappe, Argille Varicolori pass up (with local unconformities) into deep-water laminites of the Licata Formation, which in turn passes up into claystones of the Terravecchia Formation. These formations record nearcontinuous deposition through the Miocene, under deepwater conditions. Likewise, Argille Varicolori further north in the Gela Nappe pass up into claystones of the Numidian turbidites (B on Fig. 6a). Argille Varicolori also form the substrate to Aquitanian-Burdigalian-aged Numidian turbidites in central Sicily (PINTER et alii, 2018; location E on Fig. 5a). These units are deformed and unconformablyoverlain by orogen-derived, deep-water sediments termed the Reitano "flysch" of Langhian age (Grasso et alii, 1999). Further south in central Sicily (D on Fig. 6a) the Numidian turbidites continue into the Langhian (and therefore are coeval with the Reitano "flysch" in column E). These younger Numidian strata pass up into Serravallian to 


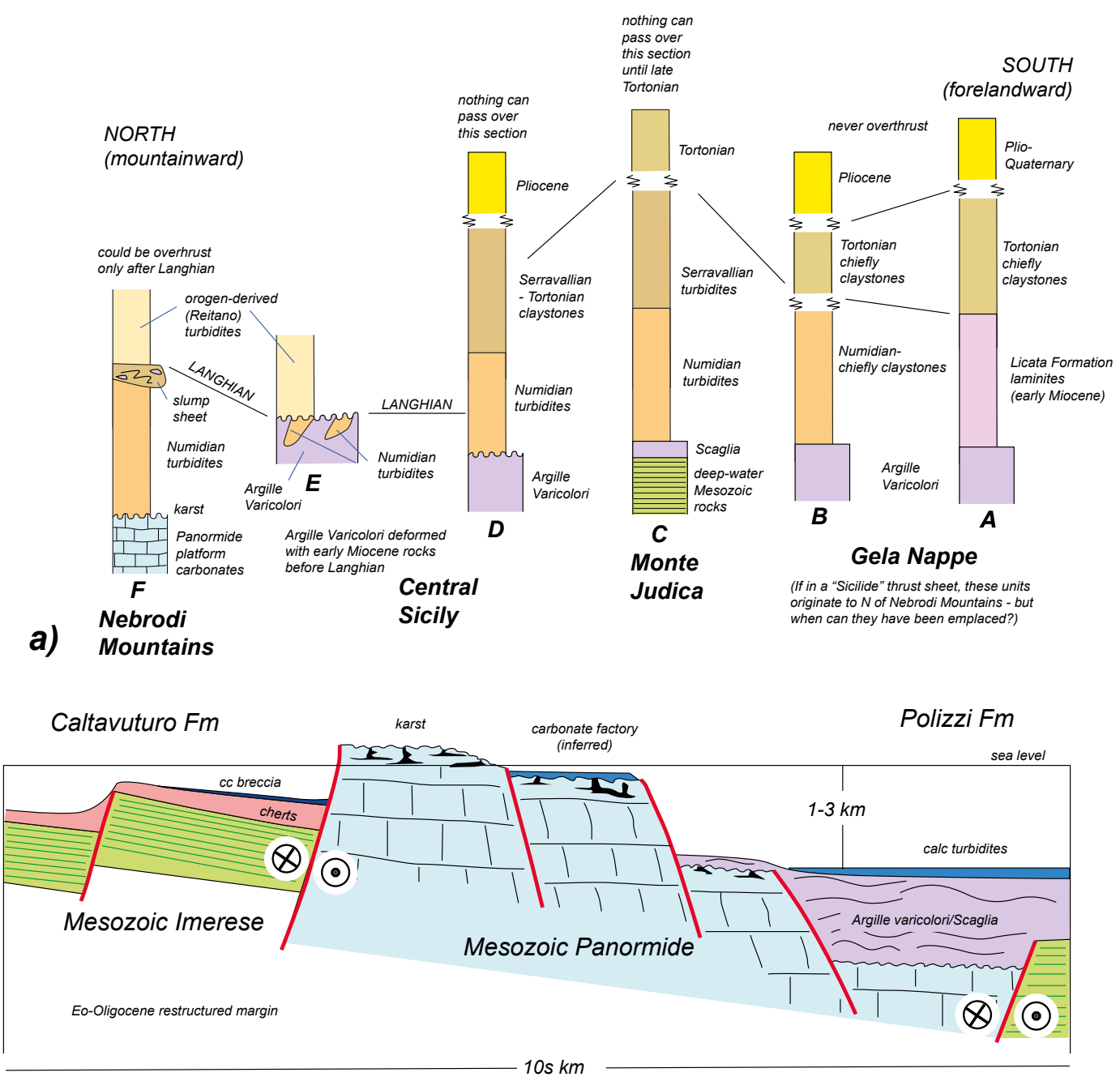

b)

Fig. 6 - (a) Summary stratigraphic columns across the thrust belt of eastern Sicily that illustrate the invalidity of the notion of a far-travelled Sicilide thrust sheet (i.e. that the Argille Varicolori substrate of the Gela Nappe were derived from the north of the Mesozoic rocks of the Madonie-Nebrodi mountains). The columns are representative of relationships at sites A-F identified on Fig. 3 . b) Schematic representation of the structural-stratigraphic relationships between distinctive tectono-stratigraphic units in the Sicilian thrust belt in Eocene-Oligocene times, just prior to thrust development and the accumulation of the Numidian turbidite system (early Miocene). The section is deliberately unoriented so as not to imply a specific restored palaeogeography.
Tortonian claystones. Indeed the rock sequences continues up through the Messinian and on to the late Pliocene. Thus, neither the Argille Varicolori of central Sicily nor its Neogene cover have been buried beneath a regional thrust sheet. This deduction, derived from primary tectonostratigraphic relationships, is confirmed by palaeothermal data (AldEga et alii, 2007; CoRRAdo et alii, 2009).

If the Argille Varicolori of the Gela Nappe (columns A and B in Fig. 6a) were contained within the same "Sicilide" thrust sheet as those of Central Sicily (columns D and E on Fig. 6a) then other Mesozoic substrate that outcrops between these locations either form part of the same thrust sheet or were buried by it. Such substrate includes the deepwater Mesozoic successions now elevated within the Monte Judica thrust culmination (location C on Fig. 3). These units are overlain by Oligocene "scaglia" facies (e.g. CARBOne et alii, 1990), a deep-water facies-equivalent to the Argille Varicolori. The Monte Judica substrate is overlain in turn by Aquitanian to Serravallian strata (including Numidian turbidites) that pass up into Tortonianaged Terravecchia claystones. Thus, the stratigraphic relationships preclude the Monte Judica rocks (column C on Fig. 6a) being overthrust by a "Sicilide" or Gela Nappe, unless it happened in later Tortonian times.
Further Mesozoic substrate outcrops in northern Sicily, forming the Madonie mountains, continuing beneath the Numidian turbidites of the Nebrodi Mountains (Fig. 3). As summarised on column F (Fig. 6a), the turbidites are Aquitanian to Burdigalian in age (PINTER et alii, 2016), capped by slump-sheets that are in turn overlain unconformably by Langhian-aged Reitano "flysch" (e.g. Grasso et alii, 1999). Thus if the Argille Varicolori of central and southern parts of the thrust belt were derived from oceanward (north, in the current geographic framework) of the Mesozoic strata of the Madonie-Nebrodi mountains, as demanded by advocates of a far-travelled Sicilide thrust sheet, they would need to have been emplaced after deposition of the Reitano flysch. This would compromise the relationships between strata of Langhian age across the region, placing the orogen-derived turbidites of column $\mathrm{F}$ far removed from their correlatives in column B (Fig. 6a) and forelandward of the sediment-starved time-equivalent successions now within the Gela Nappe (columns A and B). It also requires the Numidian rocks of the Nebrodi Mountains to have once lain in the footwall to the Sicilide thrust sheet. Yet these strata show no palaeothermal signature of such burial (Aldega et alii, 2007). 
In summary, existing interpretations consider the Argille Varicolori to have been derived from an oceanward location and to have been emplaced as a Sicilide thrust sheet that leapfrogged over all over palaeogeographic units. This means that it formed a roof thrust sheet to the other structures in the thrust belt - so these other sheets developed not as an emergent imbricate fan but as a duplex. Yet these thrust sheets record syn-kinematic deposition, in some locations continuing up into the late Pliocene (e.g. Centuripe basin: C on Fig. 6a). These stratigraphic relationships prohibit the duplex model and consequently falsify the notion of a Sicilide thrust sheet. Note that, with the exception from that reported for the Monte Judica culmination: C of Fig. 6a, discussed later, palaeothermal data from the Miocene strata (ALDEGA et alii, 2007; CORRADO et alii, 2009) definitively prohibit tectonic burial that would be a consequence of the Sicilide thrust sheet. We therefore deduce that the Sicilian thrust systems were entirely emergent during their evolution and were open to the syn-orogenic seabed (or locally subaerially exposed) through the Neogene. This contrasts with deductions made by Gasparo Morticelli et alii (2015) for structural-stratigraphic relationships in western Sicily, which are essentially adopted from those of CATALANO \& D'ARgENIo (1978). Their structural history is therefore not appropriate for central-eastern Sicily and may indeed be generally inappropriate.

\section{EVIDENCE FOR BASIN RE-STRUCTURING}

Several lines of evidence cast doubt on the use of Mesozoic stratigraphy as a guide to the pre-orogenic configuration of thrust sheets now found on Sicily. Within the Nebrodi mountains (Fig. 3), the platform carbonates of the Panormide domain are unconformably overlain by the Numidian turbidite sandstones (Fig. 6a; DewEver et alii, 2010) indicating that by the Burdigalian parts of the Panormide unit had subsided to significant water depths and certainly did not occupy a platformal, shallow-water position. Furthermore, PINTER et alii (2016) describe Cretaceous platform carbonates, capped by an erosional karstic surface overlain in turn by deep-water cherty red marlstones and thin limestones, so-called Scaglia facies (GrAsso et alii, 1978) that pass up into Numidian turbidites. As PINTER et alii (2016) point out, the Panormide domain was restructured after forming as a platform.

Increasingly it is becoming apparent that there has been extensive restructuring of the continental margins that bound parts of western Tethys during the late Cretaceous and early Tertiary (e.g. Vitale et alii, 2018 and references therein). Dispersal patterns of Mesozoic continental megafauna (e.g. ZARCONE et alii, 2010) show that emergent land masses provided continuity of continent blocks from north Africa to Apulia. Presumably these blocks were rifted, the lithosphere thinned and the emergent pathways subsided before becoming incorporated into the Maghrebian and southern Apennine thrust systems. Given the complex history of relative plate motion between Africa and Europe through the late Cretaceous and into the Cenozoic, restructuring of the continental margins of western Tethys should be entirely expected. The Madonie region of northern Sicily contains further stratigraphic evidence that Mesozoic tectono-stratigraphic units were juxtaposed and restructured before the development of the thrust systems on Sicily. The Imerese units are capped by the Eocene-Oligocene Caltavulturo Formation (e.g. AвAтE et alii, 1988), a deep-water cherty succession. However, adjacent to the Panormide domain the formation contains breccias of reworked platform carbonates together with reworked primary, shallow-water bioclasts. There are no transitional environments between deep-water Imerese and shallow-water parts of the residual Panormide platform, suggesting that these two domains have been structurally juxtaposed (e.g. Tavarnelli et alii, 2001) prior to the EoOligocene. Primary bioclasts, including shallow-water nummulites, are major components of the Eocene-aged Polizzi Formation (OGNIBEN, 1960), which is interbedded with Argille Varicolori and found in outcrops SE of the Madonie mountains. These were presumably shed into a deep-water, clay, marl and chert-prone basin adjacent to the residual Panormide platform.

A schematic representation of pre-thrusting stratigraphic relationships that honour field relationships in north-central Sicily is shown in Fig. 6b. The Mesozoic transitions between platforms and basins lie beyond the region represented by this diagram. The close proximity of these constituent palaeoenvironments is inferred here to be the product of early Tertiary faulting. As the vertical offset of these inferred faults can be no more than the differences in palaeobathymetry of pre-faulting strata, we suggest that these structures were principally strikeslip. The orientation of the faults is presently unknown, although we discuss some inferences for the locations in the SE segment of the thrust belt below.

\section{GROWTH STRATA, THE TIMING OF DEFORMATION AND STRUCTURAL EVOLUTION IN THE THRUST BELT.}

We now consider the structural and stratigraphic relationships in the eastern part of the thrust belt. Figure 7 serves as a location map to the representative crosssections used to illustrate these relationships. We contrast these geometries as portrayed by structures within the thrust wedge (Fig. 8) with those at the thrust front (Fig. 9). Our aim is to illustrate that folds and thrusts grew in parallel over a long period, that sedimentation was strongly located upon the thrust wedge rather than in a foredeep and consequently that the thrusts in the thrust wedge are ramp-dominated.

\section{DEFORMATION WITHIN THE THRUST WEDGE}

Syn-kinematic strata chart the evolution of the thrust wedge in east-central Sicily. We illustrate this by considering two cross-sections (Fig. 8). The first of these (Fig. 8a) revises mapping by CARBONE et alii (1990), building on the cross-section of GAMBINO et alii (2018). The section line includes 5 wells that penetrate lower Miocene sandstones and mudstones of the Numidian system together with their substrate of Argille Varicolori. Wells and outcrop suggest that the Numidian strata achieve thicknesses of several $\mathrm{km}$. However, in the Sperlinga syncline the Numidian strata are just $300 \mathrm{~m}$ thick and are capped conformably by siliceous marlstones of Burdigalian age. These marlstones signify a termination of the main sand input in this sub-basin. The thickness variations in the 
turbidites correspond to structures and indicate that the deposition of the Numidian system is syn-kinematic. Thus, this part of the thrust belt had begun to develop at least by Burdigalian times. Continuing deformation is charted by strata in the Mandre Basin, which now lies in the footwall to a major back-thrust. Facies and thickness variations both in late Tortonian clastics (JonEs \& GRASSO, 1997) and in Messinian evaporites (BUTLER et alii, 2015) indicate that this back-thrust had a protracted history, active for at least 3 million years. Collectively the structures in Fig. 8a) were active for most of the Miocene, and certainly for more than 10 million years.

Long-lived deformation characterises the development of the Marcasita anticline (Fig. 8b). Our cross-section uses outcrop mapping together with sub-surface data from the Morello 1 well and the Pasquasia evaporite mine (ButLer et alii,1995b). The well penetrated over $3000 \mathrm{~m}$ of chiefly lower Miocene strata in the footwall to a thrust that carried Argille Varicolori to outcrop in the core of the Marcasita anticline. These sediments lie in a growth syncline and most of the strata pinch out southwards onto the northern limb of an anticline that is cored by Argille Varicolori of the Pietraperzia inlier (BUTLER \& LicKORISH, 1997). The syncline also hosts the several hundred metres of Messinian evaporites. These pass laterally onto the flanks of the Marcasita and Pietraperzia anticlines to be represented by a few metres of Calcare di Base. Thus, the folds were active through to the end of the Miocene. Activity continued into the late Pliocene, as charted by a spectacular set of off-lapping parasequences of coastal carbonates (BUTLER AND LICKORISH, 1997) that comprise the youngest part of the thrust-top deposits. This part of the thrust belt is interpreted to have been subaerial thereafter as the regional regression swept southwards (BuTLER et alii, 1995a).

Both cross-sections, and many others in the thrust belt, demonstrate long-lived deformation on individual and arrays of folds and thrusts (Fig. 8). However, there has been rather little syn-kinematic erosion of anticline crests. The Marcasita anticline preserves a cover of Pliocene strata $8 \mathrm{~km}$ along strike of the section line of Fig $8 \mathrm{~b}$. Other strata onlap and pinch onto the flanks of the fold. Likewise, syn-kinematic strata dominate the outcrop on Fig. 8a. Presumably, the amplification of the anticlines was compensated by subsidence of the thrust belt as a whole, presumably charting the flexural loading of the underlying foreland lithosphere by the adjacent orogenic hinterland (Butler et alii, 1995a).

\section{THE THRUST FRONT}

The front of the thrust system is marked by an allochthonous sheet largely comprising previously deposited clay-dominated syn-kinematic strata and generally referred to as the "Gela Nappe" (OGNIBEN, 1969). It is illustrated here in two cross-sections (Fig. 9). The frontal structures have been penetrated by several deep exploration wells that encountered platform/shelf carbonates of the Hyblean foreland beneath nappe. These buried foreland carbonates are stratigraphically capped by the Pliocene Trubi Formation and very thin mudstones. In contrast, immediately ahead of the thrust front, the vestigial foredeep contains up to $2 \mathrm{~km}$ of Plio-Quaternary claystones and fine sandstones. Likewise, significant thicknesses of Upper Pliocene-Lower Pleistocene strata are preserved above the nappe.

In the northern section (modified after BUTLER et alii, 1995a; Fig.9a) much of the Gela Nappe is covered by Plio-Pleistocene strata that are weakly deformed and unconformably overlie folded sequences of Tortonian claystones and Messinian evaporites. These stratigraphic relationships are observed in outcrop adjacent to the line of cross-section (see Fig. 7). It seems probable that these folds are cored by Numidian clays and Argille Varicolori as these units also outcrop along strike. The frontal part of the Gela Nappe largely comprises Terravecchia claystones, Messinian evaporites and their cover of Trubi chalk, all folded together. The thrust front is buried and unconformably overlain by Pleistocene clays which onlap folded evaporites and Trubi chalk. These onlap relationships have been mapped around the town of Caltagirone (LENTINI, 1984) and provide critical evidence for the termination of displacement along this segment of the thrust front.

The southern cross-section (modified after LicKORISH et alii, 1999; Fig. 9b) illustrates structural and stratigraphic relationships equivalent to those displayed in the frontal part of Fig 9a. As in the north, here too the thrust front is overstepped by Pleistocene claystones and sandstones. The folded and thrusted Messinian evaporites, Trubi chalks and later Pliocene claystones are underlain by thickened claystones of Tortonian and possibly earlier Miocene age (the Licata Formation, lateral equivalent to the Terravecchia Formation). A key difference between the sections is that in the south there is a young thrust that cuts Pleistocene strata (Fig. 9b). This is interpreted by LICKORISH et alii (1999) as a break-back structure that represents shortening within the thrust wedge, hindward of the frontal thrust.

The stratigraphy of the buried foreland beneath the frontal Gela Nappe is known from various wells, including Settafarine (Fig. 9b) and, in the north, Ramacca 1 (Fig. 4a). The base of the Gela Nappe glides on a thin succession of Trubi chalk and a veneer of Pliocene claystones. There is no thick succession of syn-kinematic strata. These were only deposited on the thrust wedge itself and eventually, along the modern thrust front. Therefore, the emergent thrust front was largely emplaced into a submarine basin which, at the time of deformation was locally receiving very little detrital input.

\section{The Monte Judica thrust Stack}

Although much of the eastern part of the Sicilian thrust belt is covered by late-kinematic, Pliocene strata, the Monte Judica area (Fig. 7) represents an important structural culmination that reveals the structure and pre-kinematic stratigraphy (LENTINI, 1974). Existing interpretations show the area to comprise a stack of imbricate thrust slices of deep-water Mesozoic-Palaeogene carbonates together with their cover of Miocene claystones and quartz sandstones (e.g. Bianchi et alii, 1989; Fig. 4a). That this represents an exhumed, once deeply buried, part of the thrust system is evidenced by vitrinite and illite crystallinity data presented by Di PAOLo et alii (2012). These suggest peak temperatures for the exhumed Triassic strata of 100 $130{ }^{\circ} \mathrm{C}$. This culmination is rimmed by further Miocene sandstones and claystones that are grouped with inliers of 


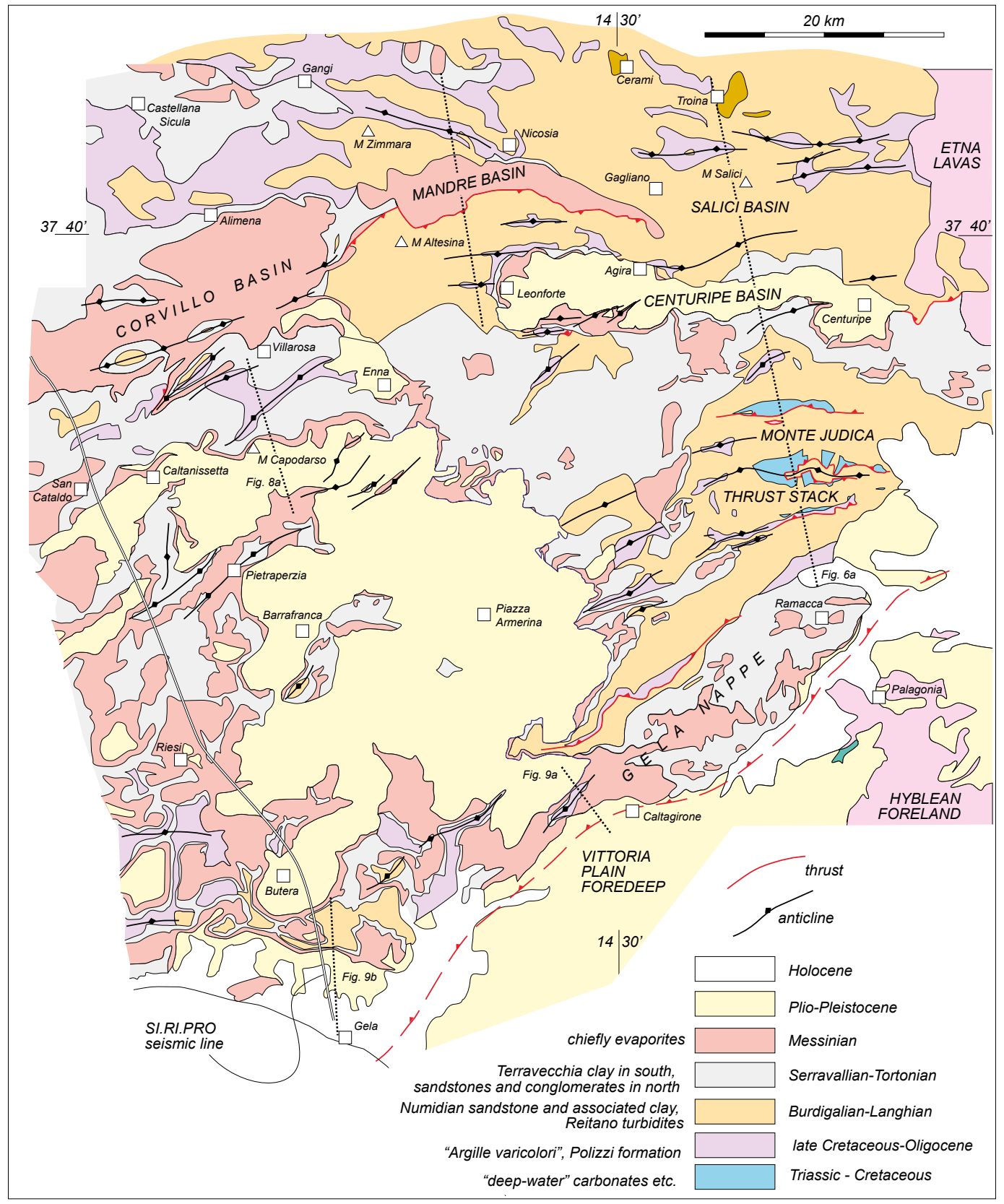

Fig - 7. Simplified and interpreted geological map of the central-eastern thrust system of Sicily (boxed area on Fig. 3). Modified by the authors own field observations, after regional synthesis by LENTINI \& CARBONE (2014) and local map sheets (LenTINI, 1984; CARBONE et alii, 1990; StURIale et alii, 2010).

Argille Varicolori. Therefore, existing interpretations argue that these rimming units are erosional remnants of a fartravelled "Sicilide" thrust sheet. Di PAOLO et alii (2012) argue that this thrust sheet provided a tectonic overburden that accounts for the peak temperatures in the culmination. As discussed earlier, the timing and distribution of synkinematic strata across the Sicilian thrust belt preclude this established interpretation. And at Monte Judica these preclusions are especially evident. As CARBONE et alii (1990) show, the imbricate slices in the Monte Judica stack contain strata up to Serravallian in age. Therefore, emplacement of any far-travelled enveloping thrust sheet would need to postdate at least the early Serravallian. However, the thrust stack including the Argille Varicolori are unconformably overlain by early Tortonian Terravecchia claystones, indeed some parts of this succession may also be Serravallian in age (CARBONE et alii, 1990). Furthermore, more northern parts of the thrust belt are overlain by Langhian strata and younger that locally postdate much of the deformation (GrAsso et alii, 1999). So, there is no viable time-window within the record of syn-kinematic strata (Burdigalian to Pleistocene) when a "Sicilide" thrust sheet could have been emplaced across the rocks that now constitute the Monte Judica imbricate stack.

A revised interpretation of structural-stratigraphic relationships at Monte Judica is presented (Fig. 10a), based on the mapping of CARBone et alii (1990). In this, Argille Varicolori form part of the pre-kinematic substrate along with the deep-water Mesozoic carbonates. At outcrop, these carbonates are capped by a veneer of a few metres of "Scaglia" red mudstones and thin carbonates (CARBONE et alii, 1990) and it is these rocks that we consider to be the immediate equivalents of the Argille Varicolori in the area (as discussed in Fig. 6). We now require an 

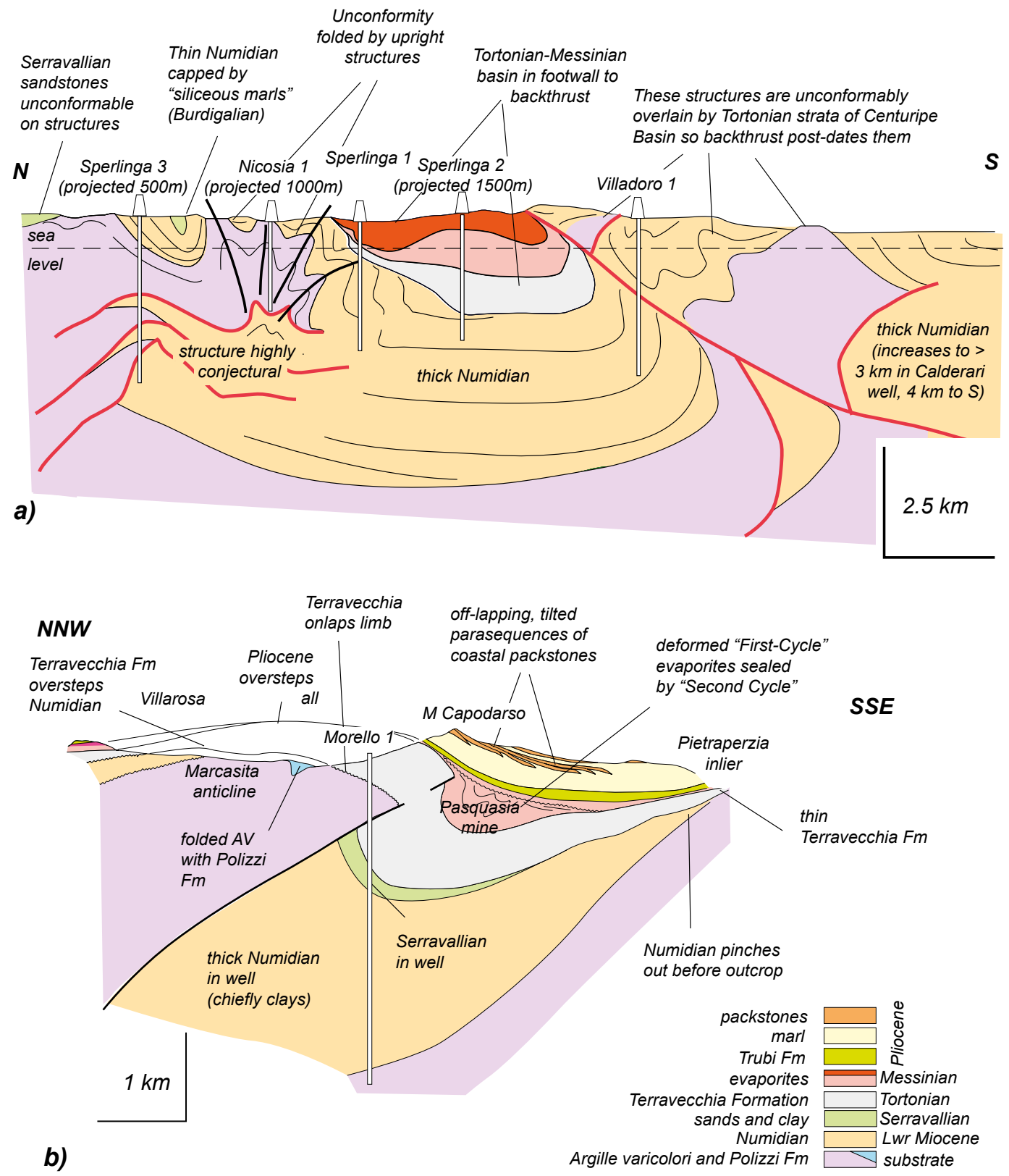

Fig. 8 - Interpretations of stratigraphic relationships within thrust-bounded basins developed on the evolving Maghrebian thrust wedge. Sections located on Fig. 7. Based on field mapping by the authors with well data as indicated. a) is after GAMBINO et alii (2018) and shows an interpretation of the deep structure Corvillo-Mandre basin, caught between a forethrust and back-thrust system (well data after CARBONE et alii, 1990). b) section through the frontal structure of the Marcasita anticline, modified after ButLer et alii (1995a).

explanation for the variations in thickness between the Argille Varicolori and "Scaglia". Consequently, we propose that the Mesozoic carbonates were faulted into a block-and-basin morphology and that these pre-orogenic normal faults then served to influence the thrust system (Fig. 10b). Following our earlier work (PINTER et alii, 2018) we further propose that the Numidian strata - of Burdigalian to Langhian age - were deposited in growing thrust-top basins. They therefore onlap the growing flanks of these basins which are currently represented by the northern (back) sides of the imbricated slices of pre-kinematic substrate. The model further explains why these sandstones and claystones around Monte Judica are as young as Serravallian, as these represent the final part of the thrust-top basin successions here (Fig. 10a, c). The older parts of the Numidian succession, here largely comprising claystones, are found in the deeper parts of the thrust-top basins, and these are exposed away from the plunge culmination of the thrust stack (CARBONE et alii, 1990).

So that a Sicilide thrust sheet can provide the necessary burial conditions to explain their palaeothermal data, Di PAOLo et alii (2012) invoke $<500 \mathrm{~m}$ stratigraphic cover of Neogene age on the pre-orogenic strata of the Monte Judica area. Our revised interpretation suggests that the Numidian strata alone may have exceeded thickness of $2 \mathrm{~km}$. Adjacent wells off the culmination (CARBONE et alii, 1990) suggest the Terravecchia may have provided an additional $>1000 \mathrm{~m}$ of burial. Collectively these synkinematic strata may have provided sufficient further burial to achieve the necessary peak temperatures in the deeper stratigraphic levels. At present, the sample locations in the study of DI PAOLO et alii (2012, and others) are insufficient to discriminate between tectonic 


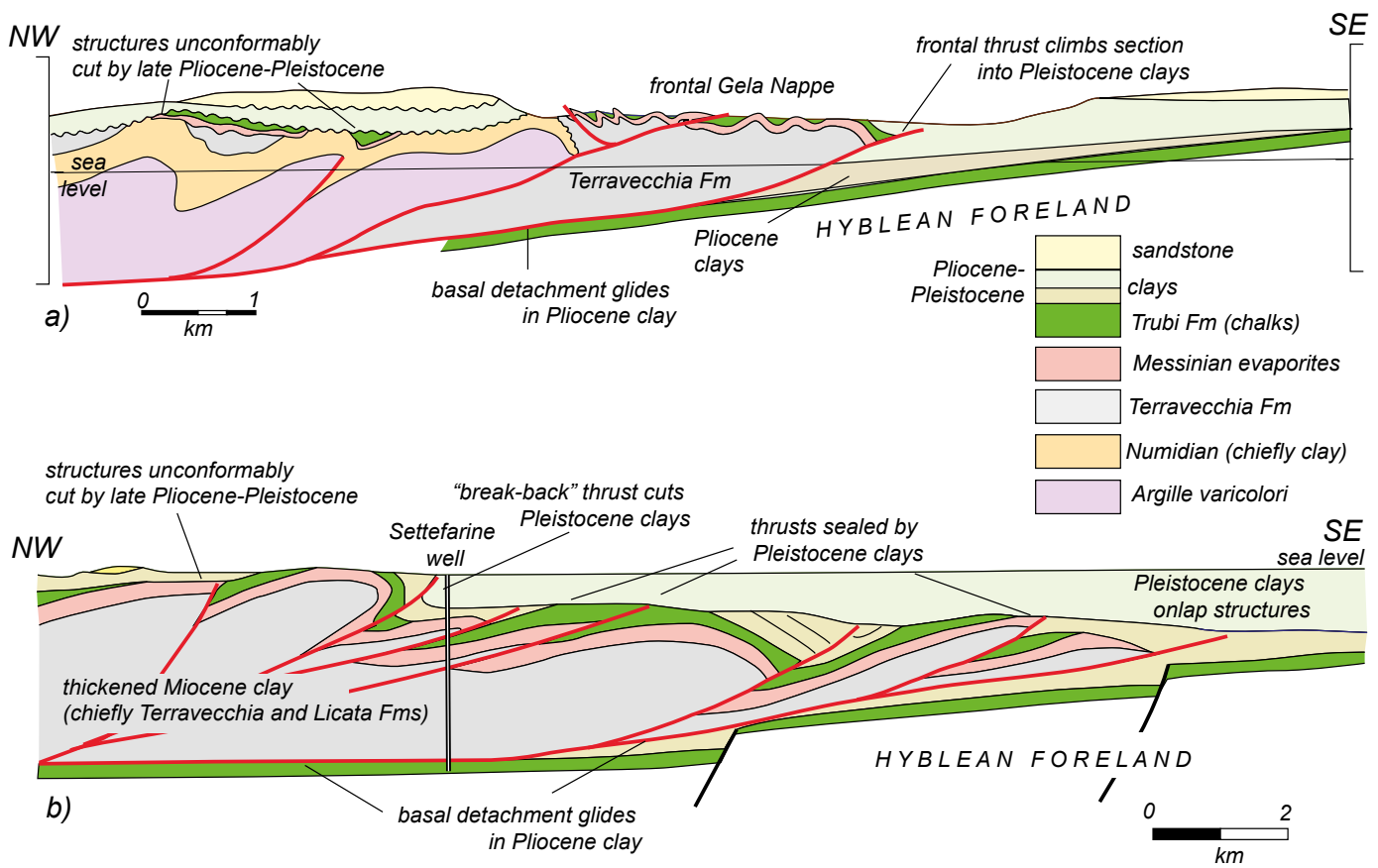

Fig. 9 - Interpretations of the Gela Thrust Front in SE Sicily showing the relationship between contractional structures, the basal thrust detachment and foredeep/ foreland sediments. Section lines are on Fig. 7. a) The thrust front near Caltagirone showing thrust ramp climb on the frontal thrusts, sealed by Pleistocene clay (section modified after BUTLER et alii (1995b). b) the thrust front near Gela, sealed by Pleistocene clays. The most recent deformation has bypassed the buried thrust front to break-back into the thrust wedge (section modified after LicKORISH et alii, 1999).
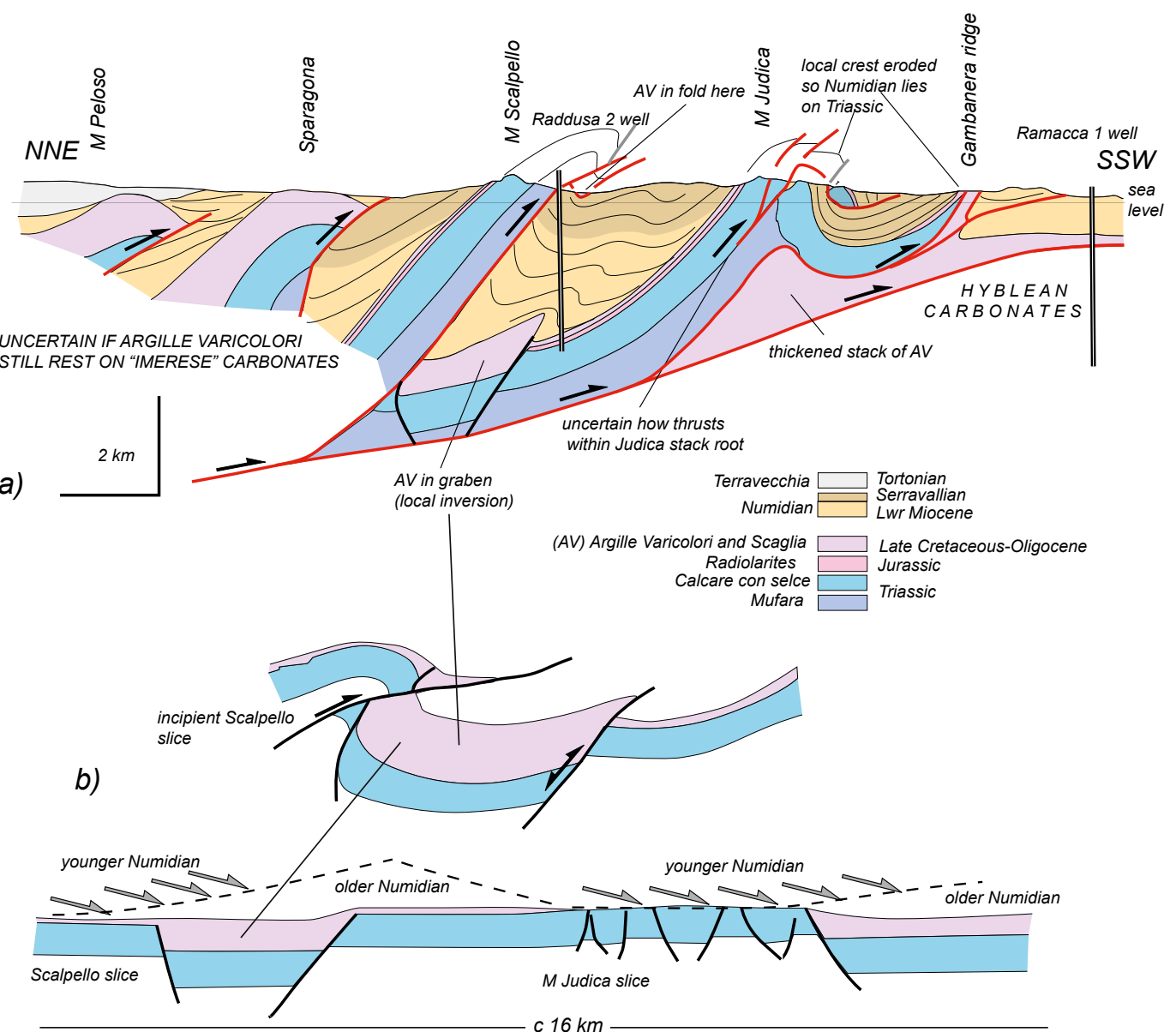

c)

Fig. 10 - Interpretation of the structural-stratigraphic relationships at Monte Judica, modified after field mapping by CARBONE et alii (1990). a) illustrates a revised cross-section depicting the inferred stratigraphic relationships between the synkinematic Numidian rocks and their substrate. b) is a schematic representation of the contractional structures initiating across the Argille Varicolori units that display laterally-variable thicknesses above a faulted substrate. c) illustrates these pre-kinematic relationships and the inferred onlap of syn-kinematic Numidian strata across them. 
and sedimentary burial. However, using our modified thicknesses of syn-kinematic strata (Fig. 10), the thickness of any over-riding thrust sheet required by DI PAOLO et alii (2012) becomes vanishingly small. Therefore, it should be possible to reconcile the palaeothermal data with the deductions from stratal relationships that the Mont Judica culmination was never buried beneath a fartravelled thrust sheet.

Our explanation for the Monte Judica thrust stack is consistent with the behaviour of thrust systems that emerge into areas receiving significant syn-kinematic sedimentation, in this case the influx of lower Miocene clays and sands. The thrust slices are separated by these younger rocks and climb ramps. It is these relationships that create the culmination in this part of the thrust belt. Just ahead of each of the main thrust slices, of Monte Judica and Monte Scalpello, there are folded subsidiary thrust slices that locally create downward-facing folds and fault segments (Fig. 10a). The main thrust slices apparently cut across and over-step these complications, in a similar fashion to that interpreted for the seismic example from the Niger delta (Fig. 2c-e). Note that, at Monte Judica, only the deeper levels of these ramps are preserved. It is likely that deformation continued into the later Miocene.

Within the eastern thrust belt, the structure changes away from the Monte Judica culmination. To the west the thrust belt has a more subdued relief and is largely masked by Tortonian and younger syn-to-late kinematic strata (Fig. 7). Inliers of pre-kinematic strata exclusively comprise Argille Varicolori and it is this substrate that underpins outcrop of the thrust wedge of the Caltanissetta Basin (Fig. 3). It is possible that a major basin-bounding structure for the Argille Varicolori lay just west of the modern position of the Monte Judica culmination and it is the resultant distribution of the different pre-kinematic successions that control thrust belt structure.

\section{A MODEL FOR THRUST WEDGE EVOLUTION}

The timing of syn-kinematic strata is compiled on a cross-section across the eastern part of the thrust belt (Fig. 11). This follows the line of section of CARBone et alii (1990; Fig. 4a; see also Bianchi et alii, 1989) but includes the Gela Nappe (BUTLER et alii, 1992). Note that the deep structure of this section, specifically the depth to the floor thrust and the internal content and structure of the pre-kinematic rocks, are poorly constrained. The interpretation is modified after PINTER et alii (2018) and, in contrast to earlier interpretations, considers the Numidian system to represent the fill to thrust-top basins rather than form far-travelled thrust sheets of ancestral foredeep deposits (c.f. Di Paolo et alii, 2014; Gasparo Morticelli et alii, 2015). Thus, the thrust wedge initiated in or just before Burdigalian time. Following ButLer et alii (1995a), the regional regression surface that caps thrusts and folds become progressively younger to the south (late Pliocene into early Pleistocene), dating the progressive termination of deformation within the thrust wedge (Fig. 11).

The complete history of deformation and the activity are difficult to establish for most of the thrust-top basins, because, along this line of section, the upper part of their stratigraphic record has been eroded. Ubiquitously at outcrop, all the Numidian strata are deformed, as typified by Fig. 8 b, indicating that deformation continued into the middle Miocene in these localities. However, projection from adjacent areas of the thrust belt to the west, where younger strata are preserved (Fig. 7), allows some additional insight.

Thus, the Centuripe basin lies in the hangingwall to the Altesina back thrust, the footwall syncline to which developed from the late Tortonian to the early Pliocene (Butler \& Grasso, 1993; Butler et alii, 2015). Likewise, the southward-directed (forelandward) thrusts beneath and at the southern edge of the Centuripe basin are sealed by Terravecchia clays that are themselves tilted and slumped.

\section{NNW}

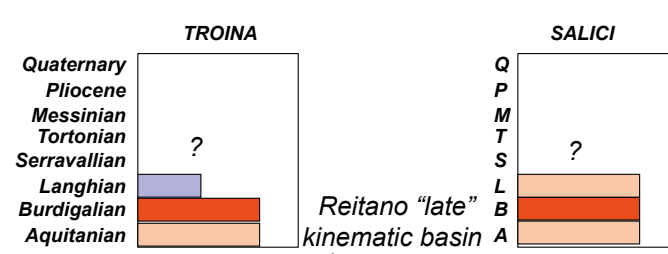

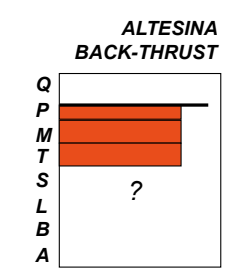
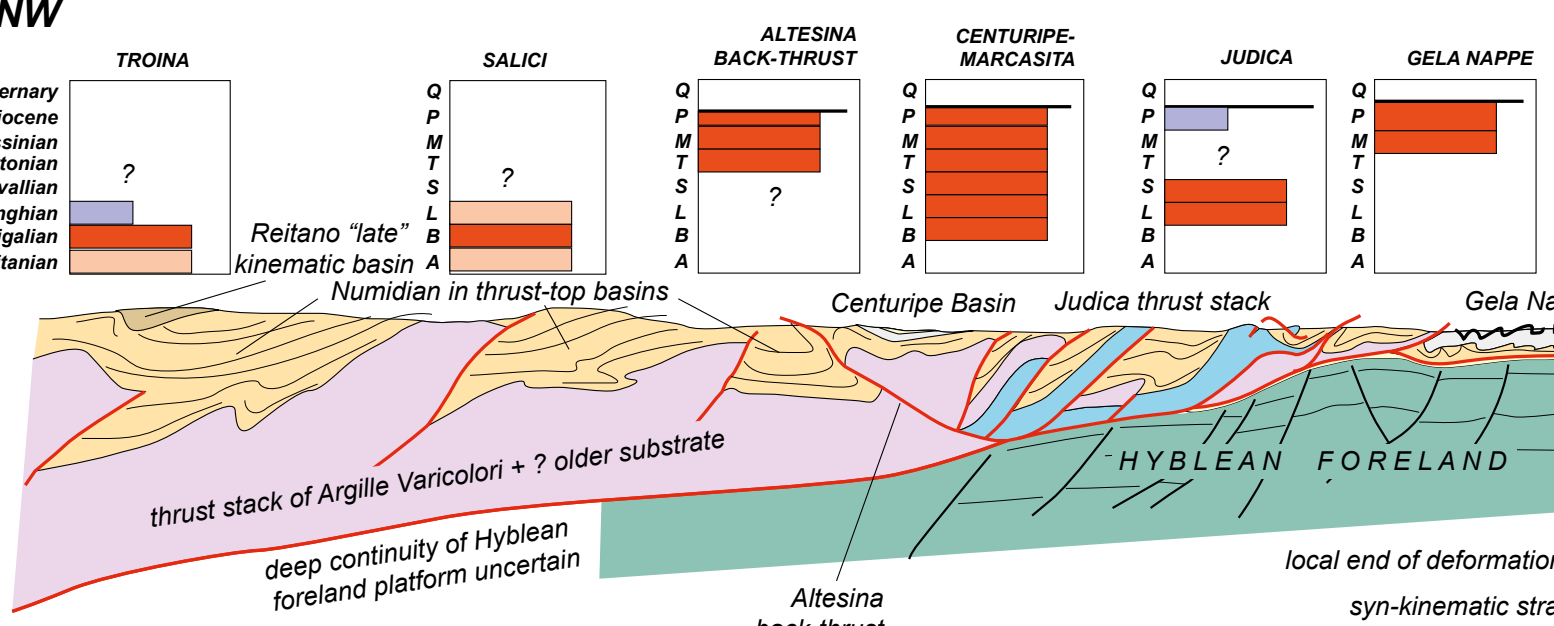

SSE 
Projecting the relationships on Fig. 8a from along trend to the west of Enna (Fig. 7), suggests that these structures were active throughout the Miocene (Fig. 8b).

In contrast to much of the thrust wedge, the Gela Nappe contains only few strata that pre-date the Terravecchia Formation. It seems probable that this part of the Terravecchia was deposited ahead of the ancestral thrust wedge and therefore represents foredeep, rather than thrust-top sedimentation (BuTLER et alii, 1992). However, certainly by the Messinian, these strata had been accreted into the thrust wedge as evidenced by growth strata and short-range facies changes in the evaporites across folds within the Gela Nappe. Deformation in these frontal structures continued during the Pliocene (BUTLER et alii, 1995a).

\section{DisPLACEMENT PARTITIONING IN THE THRUST WEDGE}

The integration of stratigraphic interpretations, allied to the work of Pinter et alii $(2016,2018)$ conforms to the description of the thrust wedge in eastern Sicily provided by ButLeR \& LickoRish (1997). They argue for structures within the wedge to be long-lived, having operated not in a sequence but in parallel. Displacement on thrusts, and shortening across folds is relatively small. BUTLER \& LICKORISH (1997) estimate $<5 \mathrm{~km}$ shortening across the southern part of the thrust wedge since the Messinian at a time-averaged rate of less than $1 \mathrm{~mm} / \mathrm{yr}$. These values are broadly in agreement with those obtained by BuTLER et alii (1992) for the Gela Nappe near Ramacca (Fig. 7) along the line of section of Fig. 11. In contrast, a simple line-length measurement implies c $10 \mathrm{~km}$ of shortening on the Monte Judica thrust stack (Fig. 10a). Integrating these figures across the section line of Fig. 11 suggests a total shortening across the thrust wedge of $20-30 \mathrm{~km}$.

Displacements across the thrust system are generally considered to greatly exceed those estimated above. Palaeomagnetic data (summarised by CifELLi et alii, 2007) indicate that the Scaglia of the Monte Judica thrust stack has experienced c 90-100 degrees clockwise rotations. These rotations decrease systematically in younger, synkinematic strata. Thus, the thrust belt developed by rotational, foreland-directed thrusting. Assuming 90 degree clockwise rotation about a pole in SW Sicily (c. 150 $\mathrm{km}$ from the Monte Judica thrust stack and the section line of Fig. 11) we can establish a horizontal translation for the thrust wedge of $235 \mathrm{~km}$ (see also Speranza et alii, 2018). As the thrust wedge only accommodates about $20-30 \mathrm{~km}$ of shortening, the basal detachment must accommodate about $200 \mathrm{~km}$ displacement. There are substantial uncertainties in these estimates, but the general pattern is clear - displacements on the eastern Sicilian thrust belt were very strongly partitioned onto the basal thrust detachment and not within the thrust wedge.

\section{DISCUSSION}

The controls on the evolution of the thrust wedge exerted by varying the distribution of syn-kinematic sedimentation can be explored schematically (Fig. 12). The thrust front represents the emergence of a basal detachment that follows a thrust flat. In essence it must climb onto the synkinematic seabed and this cannot receive any appreciable sedimentation. Rather, sedimentation must accumulate near-exclusively upon the thrust wedge and, together

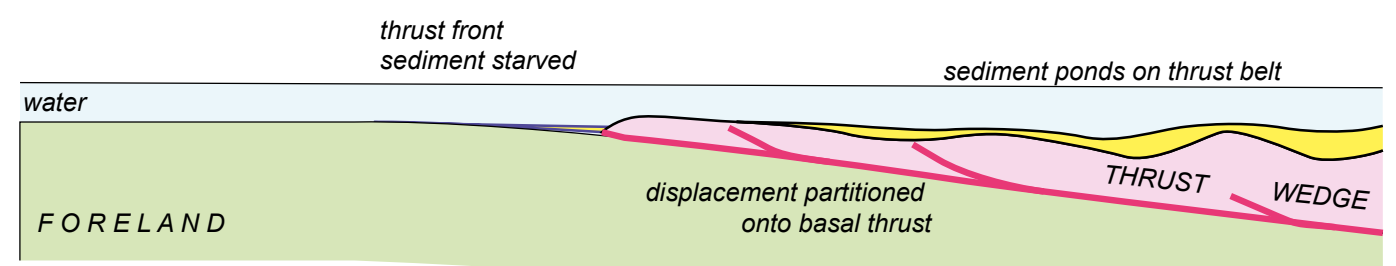

a)

foreland

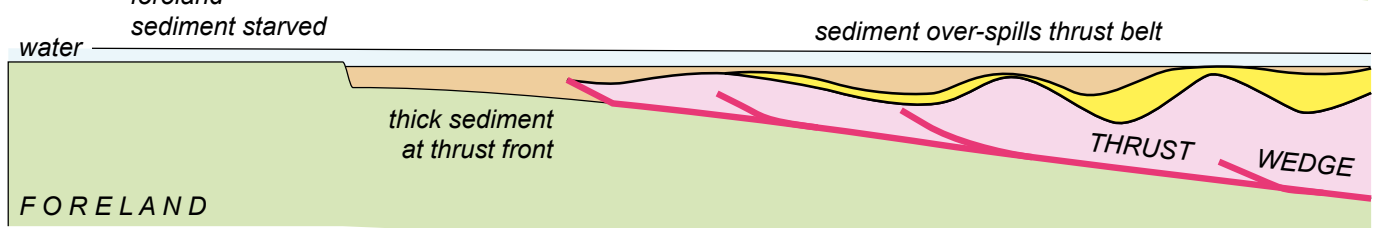

b)

foreland

sediment starved thrust climbs - or accretes foredeep sediment into wedge

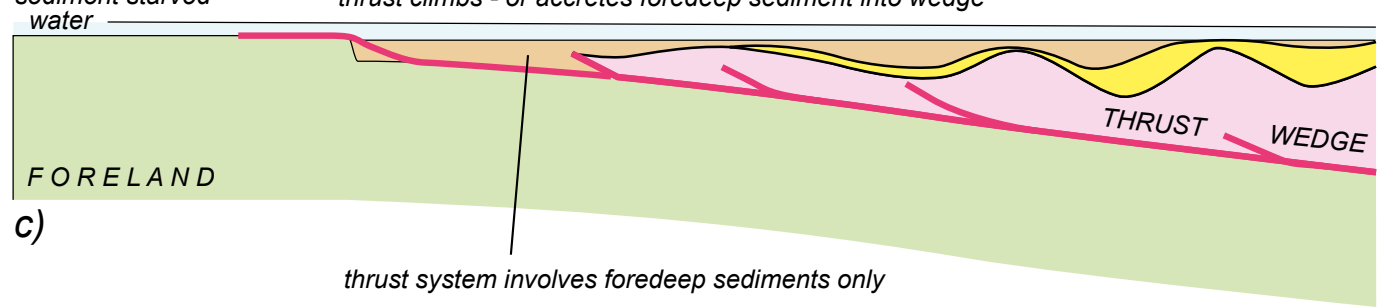

Fig. 12. - Idealised model showing the relationship between the sites of synkinematic sedimentation and the structural evolution of a thrust wedge. a) shows the stable development of a thrust wedge gliding over a sediment-starved foreland and ponding syn-kinematic sediment in thrust-top basins. This tectono-stratigraphic style is inferred here for much of the Mio-Pliocene evolution of the eastern Sicily thrust belt. b) illustrates an overspill of sediment from the thrust wedge into the foreland. This in turn requires the thrust wedge to evolve (c), either climbing a ramp or accreting this new sediment onto its front (inferred here to have happened in Sicily). 
with minor thrusting and folding, be responsible for maintaining the necessary mechanical taper to achieve the large displacements. These structural-stratal relationships are found in eastern Sicily, as described above. Sediment ponding is found in the thrust-top basins. Although wellpenetrations behind the thrust front confirm that there was very limited sedimentation ahead of the advancing thrust wedge until it encountered the modern foredeep, these only constrain the last few $\mathrm{km}$ of displacement. However, the frontal parts of the thrust belt, represented by the Licata Formation, testify to very low sediment accumulation rates during the Miocene too.

The single far-travelled thrust wedge model of Fig. 12a breaks down in detail for eastern Sicily, specifically for the late Tortonian. Terravecchia clays of this age, together with their Messinian cover, appear to have been deposited ahead of the thrust wedge (ButLer et alii, 1992; Fig. 12b). This might have been expected to have promoted rampclimbing at the thrust front, as seen for example in the Pleistocene as the thrust wedge entered the modern foredeep. However, an alternative response is for the thrust front to simply accrete the entire foredeep succession - in a similar fashion to descriptions of subduction-accretion complexes (e.g. LEgGetT et alii, 1979; Fig. 12c). The content and structure of the Gela Nappe, that now contains these accreted foredeep deposits, is rather different to the rest of the thrust belt, as it contains very little pre-kinematic strata. Thus, the late Tortonian is a relatively unusual period for the thrust wedge in eastern Sicily and perhaps reflects enhanced sediment supply, so that accommodation space on the thrust wedge was overfilled and the excess sediment bypasses for once into the foredeep. This only seems to have happened once more, at the very end of the tectonic history and at a time when the thrust wedge was finally exhumed from below sea-level, perhaps due to tectonic unloading in the orogenic hinterland (e.g. ButLER et alii., 1995a).

Developing from the model of rotational overthrusting, a series of competing scenarios can be proposed for the structure of the Sicilian thrust belt that can then be challenged by the findings developed here. The first of these (Fig. 13a) configures the thrust belt as a simple emergent imbricate fan, where displacements are distributed equally across an array of thrusts. Assuming the overarching conventional emergent imbricate stack

a)

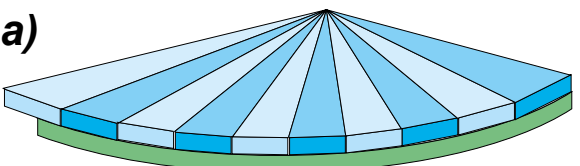

$\checkmark$

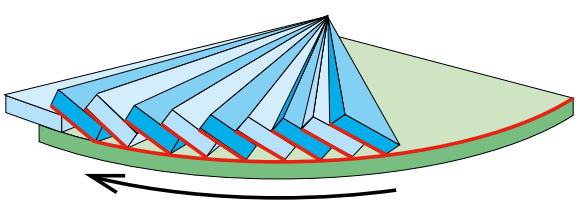

system migrates forwards in sequence large-scale repetition
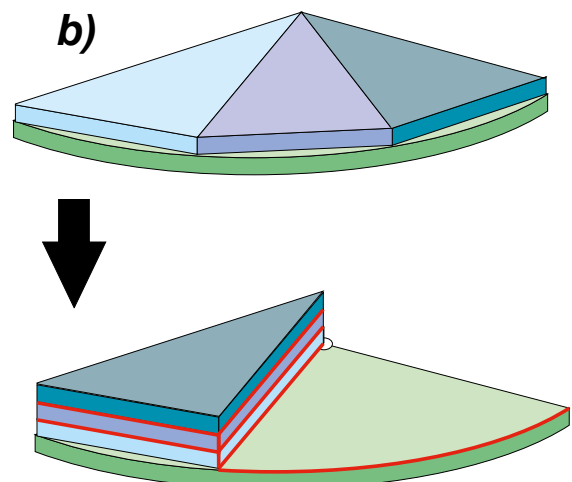

flat-on-flat stacking of sheets

\section{preferential partitioning onto basal detachment}
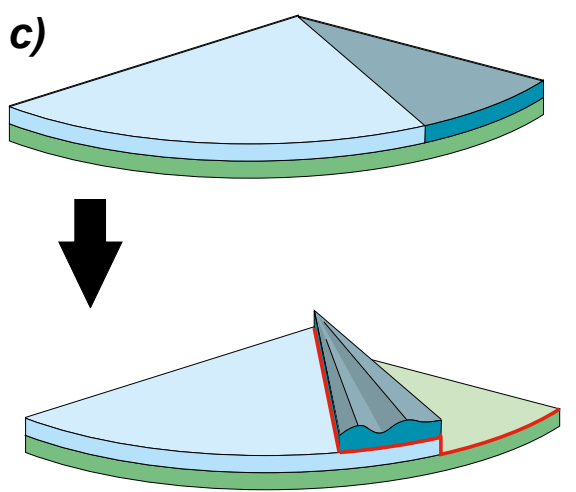

$\checkmark$

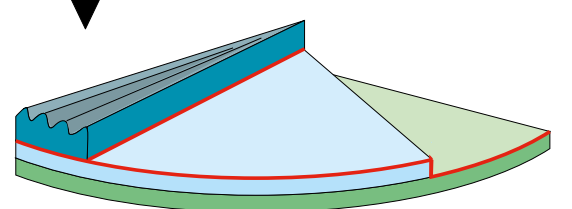

long foreland panel.....

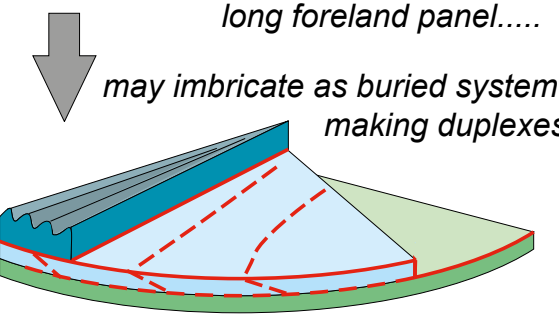

Fig. 13 - Conceptual representations of rotational overthrusting applied to eastern Sicily, viewed towards SW and with the more internal thrust sheets stripped away to depict the deep structure.

a) a conventional representation of the thrust belt as an emergent imbricate fan.

b) depicts the thrust belt as formed as a few large-extent, large-displacement thrust sheets (essentially the model of CATALANO et alii, 2013; and GASPARO MorTiCELLI et alii, 2015).

c) the geometry preferred here shows the thrust belt as an imbricate fan but with displacements strongly partitioned preferentially onto the basal thrust. 
premise of this paper, that syn-kinematic sedimentation inhibits the activation of upper thrust flats and promotes thrusts climbing ramps, in this scenario the thrusts would have relatively minor displacements. Therefore, in order to accumulate the total rotation of the thrust belt, there must be many thrusts. Note that in this example the tectonic rotations aggregate so that the most internal thrust sheet experiences the greatest rotation, and the most forelandward one the least. The existing palaeomagnetic data from eastern Sicily (reviewed by CIFELLI et alii, 2007; and discussed above) indicate that rotations in the thrust belt relate to the age of the strata and not to the relative position (hinterlandward or forelandward) of the thrust sheet itself. Thus, the palaeomagnetic results do not support this scenario (Fig. 13a).

In the second configuration (Fig. 13b), the thrust belt is formed of a few, far-travelled thrust sheets that are stacked above each other. The model as shown here assumes that thrust slices are accreted into the thrust wedge along its leading edge in a manner equivalent to that developed in the traditional "duplex model" of Boyer \& Elliott (1982). For this geometry to adhere to the premise of our paper, there can be no appreciable synkinematic sedimentation ahead of any of the thrust slices as they develop. Only the uppermost thrust slice, the top of the thrust wedge, would be permitted to accumulate syn-kinematic sediment.

The second configuration (Fig. 13b) is essentially that of CATALANO et alii (2013), which invokes frontal accretion of thrust slices. Their interpretation of subsurface structure would require modification to conform to the requirements of our model as these authors infer the presence of syn-kinematic strata between the thrust slices and significant syn-kinematic deposition at the emergent thrust break (GASPARO Morticelli et alii, 2015). Furthermore, if the deep structure of the thrust belt comprises stacked thrust sheets then each accretion to the evolving thrust wedge might be expected to have generated a phase of rapid uplift. These abrupt wedgethickening events are illustrated by GASPARO MORTICELLI et alii, (2015). However, it is not clear how this can be compatible with the stratigraphic record of the thrust wedge. For example, the NW corner of our study area (around Castellana Sicula, Fig. 7), which coincides with the SiRiPRO transect used by Catalano et alii (2013), remained close to sea level during the climax of these proposed thickening events (from Serravallian to early Pliocene times). There is little evidence to support pulsed episodes of rapid uplift of the thrust wedge implied by this scenario (Fig. 13b).

In a third configuration (Fig. 13c), the thrust belt is portrayed with displacements strongly partitioned onto the basal detachment. The thrust wedge modifies its shape and volume only gradually, by slow deformation and by accumulating sediment in thrust-top basins. However, in contrast to the modest displacements within, the entire thrust wedge is translated and rotated over a continuous footwall. In this fashion it experiences the bulk of the forelandward rotation. In accord with palaeomagnetic results (CifELli et alii, 2007), there is little differential rotation between parts of the thrust belt, but there is between the thrust wedge and the orogenic foreland of the Hyblean plateau. The buried foreland beneath the thrust wedge may deform during the translation of the thrust wedge, for example by imbrication. However, these underlying structures would form buried beneath the thrust wedge, they would not climb directly with the syn-orogenic surface and thus would not contain synkinematic sediments. In a Sicilian context, significant successions of syn-kinematic sediments are restricted to lie upon the thrust wedge. Therefore, any deep structure beneath the thrust wedge must be limited to pre-kinematic strata alone. This requirement is fulfilled in the crosssection of LeNTINI et alii (1996; Fig. 5c). In contrast, the interpretations of the SiRiPRO profile by CATALANO et alii, (2013) and Gasparo Morticelli et alii, 2015) both show the incorporation of syn-kinematic strata at deep levels in the thrust stack (Fig. 5b) and are therefore incompatible with the behaviour of emergent thrust systems outlined here.

\section{CONCLUSIONS}

The Maghrebian thrust system of eastern Sicily developed as an emergent imbricate fan, active from the Burdigalian, or slightly earlier, through into the Pleistocene, accompanied by substantial clock-wise tectonic rotations. Sedimentation was strongly ponded on the thrust wedge so that the evolving thrust front sediment-starved for much of this period. Consequently, the floor thrust to this system was able to glide across the syn-kinematic sea-bed and was not forced to climb ramps across foredeep sediment. This in turn promoted partitioning of displacement strongly onto this basal thrust. As Cifelli et alii (2007) and SPERANZA et alii (2018) report, there is little significant difference in the amount of tectonic rotation experienced by contemporaneous tectono-stratigraphic units, and the thrust wedge as a whole records decreasing rotations through time. These results indicate that the thrust belt does not contain large displacements between individual thrust sheets, but these were rotated together, with respect to the orogenic foreland.

Our tectono-stratigraphic study here is consistent with the palaeomagnetic results and conforms to understanding of structural evolution in emergent thrust systems that are receiving syn-kinematic sedimentation. Thrust structures within the wedge are ramp-dominated and developed at strain rates substantially slower than along the thrust front and basal detachment. Many existing tectonic syntheses of the Sicilian thrust system are improbable because they use structural evolutions that are inappropriate to emergent thrust belts. Pre-kinematic strata ubiquitous restore to underlie their local Mio-Pliocene successions - effectively eliminating the need for implausibly thin, far-travelled allochthonous sheets such as the "Sicilide". The prominence of these far-travelled sheets in existing models of the Sicilian thrust belt rely on preconceived palaeogeographic reconstructions that are inherently highly uncertain, being simply assumed rather than based on demonstrable field relationships. The syn-kinematic stratigraphic record implies that while the thrust wedge as an entity displays large allochthoneity, its constituent tectono-stratigraphic units do not. The record of synkinematic strata and their distribution offer additional constraints on subsurface interpretations in thrust belts that are currently under-utilised. We hope that the methods we have developed here will help to reduce uncertainty in the interpretation of emergent thrust belts in general. 


\section{ACKNOWLEDGEMENTS}

We are indebted to the generosity of the late Fabio Lentini. While he may not have agreed with our findings, he nevertheless openly and cheerfully shared his mapping and insight of Sicilian geology. This work also builds upon many years' collaboration between us, initiated by the late Mario Grasso (the Pantagruelian Master of Speranza et alii, 2018). The mapping of Lentini, Grasso and colleagues represents a remarkable resource for future geologists. We dedicate this contribution to their memory. We thank Sveva Corrado and an anonymous referee for constructive comments on an earlier draft of this paper. Butler's Sicilian field research has been variously funded by the UK's Natural Environment Research Council and the Royal Society. Maniscalco acknowledges "Fondi per la Ricerca di AteneoPiano per la Ricerca 2016/2018". Pinter was supported through a PhD grant funded by the BG Group (now Shell) and Brazil's National Council for Scientific and Technological Development (CNPq).

\section{REFERENCES}

Abate B. Catalano R. \& Renda P. (1978) - Schema geologico dei Monti di Palermo (Sicilia). Bollettino della Societa` Geologica Italiana, 97, 807-819.

Albanese C. \& Sulli A. (2012) - Backthrusts and passive roof duplexes in fold-thrust belts. The case of Central-Western Sicily based on seismic reflection data. Tectonophysics, 514-517, 180-198.

Aldega L., Corrado S., Grasso M. \& Maniscalco R. (2007) - Correlation of diagenetic data from organic and inorganic studies in the Apenninic-Maghrebian fold-and-thrust belt: a case study from Eastern Sicily. Journal of Geology, 115, 335-353.

Avellone G., Barchi M.R., Catalano R., Gasparo Morticelli M. \& Sulli A. (2010) - Interference between shallow and deep-seated structures in the Sicilian belt, Italy. Journal of the Geological Society, London, 167, 109-126.

Bello M., Franchino A. \& Merlini S. (2000) - Structural model of eastern Sicily. Memorie della Società Geologica Italiana, 55, 61-70.

Bianchi F., Carbone S., Grasso M., Invernizzi G., Lentini F., Longaretti G., Merlini S. \& Mostardini F. (1989) - Sicilia Orientale: profilo geologico Nebrodi-Iblei. Memorie della Società Geologica Italiana, 38, 429-458.

Bonnet C., Malavieille J. \& Mosar J. (2008) - Surface processes versus kinematics of thrust belts: impact on rates of erosion, sedimentation, and exhumation - Insights from analogue models. Bulletin de la Société Géologique de France, 179, 297-314.

Boyer S. \& ElLiott D. (1982) - Thrust systems. Bulletin of the American Association of Petroleum Geologists, 66, 1196-1230.

Broquet P. (1972) - Etude Geologique de la Region des Madonies (Sicile). Geologica Romana, 11, 1-114.

Burollet P.F., Mugniot J.M. \& Sweeney P. (1977) - The geology of the Pelagian block: the margins and basins off southern Tunisia and Tripolitania. In: the ocean basins and margins 4B (Ed. by A.F.M. Nairn,W.H. Kanes \& F. G. Stohly), 337-359. Plenum Press, New York.

ButLer R.W.H. (1987) - Thrust sequences. Journal of the Geological Society, London, 144, 619-634.

ButLER R.W.H. (2004) - The nature of 'roof thrusts" in the Moine Thrust Belt, NW Scotland: implications for the structural evolution of thrust belts. Journal of the Geological Society, London, 161, 849859.

BUTLER R.W.H. (in review) - Syn-kinematic strata influence the structural evolution of emergent fold-thrust belts. Special Publications of the Geological Society, London.

ButLer R.W.H. \& Grasso M. (1993) - Tectonic controls on base level variations and depositional sequences within thrust-top and foredeep basins: examples from the Neogene thrust belt of central Sicily. Basin Research 5, 137-151.

BUTLER R.W.H. \& LicKoRISH W.H. (1997) - Using high resolution stratigraphy to date fold and thrust activity: examples from the Neogene of South-central Sicily. Journal of the Geological Society, London, 154, 633-643.

BUTLER R.W.H. \& PATON D.A. (2010) - Evaluating lateral compaction in deepwater fold and thrust belts: how much are we missing from Nature's Sandbox? GSA Today, 20, 4-10.
Butler R.W.H., Grasso M. \& La Manna F. (1992) - Origin and deformation of the Neogene-Recent Maghrebian foredeep at the Gela Nappe, SE Sicily. Journal of the Geological Society, London, 149 547-556.

Butler R.W.H., Grasso M. \& LicKorish W.H. (1995a) - Plio-Quaternary megasequence geometry and its tectonic controls within the Maghrebian thrust belt of south-central Sicily. Terra Nova 7, 171-178.

Butler R.W.H., Lickorish W.H., Grasso M., Pedley H.M. \& Ramberti L. (1995b) - Tectonics and sequence stratigraphy in Messinian basins, Sicily: constraints on the initiation and termination of the Mediterranean 'salinity crisis'. Bulletin of the Geological Society of America, 107, 425-439.

Butler R.W.H., Grasso M., Gardiner W. \& Sedgeley D. (1997) Depositional patterns and their tectonic controls within the PlioQuaternary carbonate sands and muds of onshore and offshore SE Sicily (Italy). Marine and Petroleum Geology, 14, 879-892.

Butler R.W.H., Bond C.E., Cooper M.A. \& WatKins H.M. (2018) Interpreting structural geometry in fold-thrust belts: why style matters. Journal of Structural Geology, 114, 251-273.

Butler R.W.H., Maniscalco R., Sturiale G. \& Grasso M. (2015) Stratigraphic variations control deformation patterns in evaporite basins: Messinian examples, onshore and offshore Sicily (Italy). Journal of the Geological Society, London, 172, 113-124.

Carbone S., Catalano S., Grasso M., Lentini F. \& Monaco C. (1990) Carta Geologica della Sicilia Centro-Orientale (1:50.000). Società Elaborazioni Cartografiche, Firenze.

Catalano R. \& D' ARgEnio B. (1978) - An essay of palinspastic restoration across Western Sicily. Geologica Romana, 17, 145-159.

Catalano R. \& D'Argenio B. (1990) - Hammering a Seismic Section. Field trip in Western Sicily, Guidebook. Dipartimento di Geolologia e Geodesia Universia di Palermo, 19-22.

Catalano R., Di Stefano P., Sulli A. \& Vitale F.P. (1996) - Paleogeography and structure of the central Mediterranean: Sicily and its offshore area. Tectonophysics, 260, 291-323.

Catalano R., Valenti V., Albanese C., Accaino F., Sulli A., Tinivella U., Morticelli M.G., Zanolla C. \& Giustiniani M. (2013) - Sicily's foldthrust belt and slab roll-back: the SI.RI.PRO. seismic crustal transect. Journal of the Geological Society, London, 170, 451-464.

Catalano S., Pavano F., Romagnoli G. \& Tortorici G. (2018) - Late Tortonian-Quaternary tectonic evolution of central Sicily: the major role of strike-slip deformation. Geological Magazine, 155, 536-548.

Cifelli F., Mattei M. \& Rossettr F. (2007) - Tectonic evolution of arcuate mountain belts on top of retreating subduction slab: The example of the Calabrian Arc. Journal of Geophysical Research, 112, B09101.

Corrado S., Aldega L., Balestrieri M.L., Maniscalco R. \& Grasso M. (2009) - Structural evolution of the sedimentary accretionary wedge of the alpine system in Eastern Sicily: thermal and thermochronological constraints. Geolocial Society of America Bullettin, 121, 1475-1490.

Decima D. \& Wezel F.C. (1973) - Late Miocene evaporites of the central Sicilian Basin, Italy. Initial Reports of the Deep Sea Drilling Project, 13, 1234-1241.

Dewever B., Berwouts I., Swennen R., Breesch L. \& Ellam R.M. (2010) Fluid flow reconstruction in karstified Panormide platform limestones (north-central Sicily): Implications for hydrocarbon prospectivity in the Sicilian fold and thrust belt. Marine and Petroleum Geology, 27, 939-958.

Di Paolo L., Aldega L., Corrado S. \& Mastalerz M. (2012) - Maximum burial and unroofing of Mt. Judica recess area in Sicily: Implication for the Apenninic-Maghrebian wedge dynamics. Tectonophysics, 530, 193-207.

Di Paolo L., Olivetti V., Corrado S., Aldega L., Balestrieri M.L. \& Maniscalco R. (2014) - Detecting the stepwise propagation of the Eastern Sicily thrust belt (Italy): insight from thermal and thermochronological constraints. Terra Nova, 26, 363-371.

ElLiott D. \& Johnson M.R.W. (1980) - Structural evolution in the northern part of the Moine thrust belt, NW Scotland. Transactions of the Royal Society of Edinburgh, Earth Sciences, 71, 69-96.

Elter P., Grasso M., Parotto M. \& Vezzani L. (2003) - Structural setting of the Apennine-Maghrebian thrust belt. Episodes 26, 205-211.

Gambino S., Fazio E., Maniscalco R., Punturo R., Lanzafame G., Barreca G. \& ButLER R.W.H. (2018) - Fold-related deformation bands in a weakly buried sandstone reservoir analogue: a multi-disciplinary case study from the Numidian (Miocene) of Sicily (Italy). Journal of Structural Geology, 118, 150-164. 
Gasparo Morticelli M., Valenti V., Catalano R., Sulli A., Agate M., Avellone G., Albanese C., Basilone L. \& Gugliotta C. (2015) - Deep controls on Foreland Basin System evolution along the Sicilian Fold and Thrust Belt. Bulletin de la Société géologique de France, 186, 273-290.

GRANATH J.W. \& CASERo P. (2004) - Tectonic setting of the petroleum systems of Sicily. In: Deformation, Fluid Flow and Reservoir Appraisal in Foreland Fold-and-Thrust Belts (Ed. by R. Swennen, F. Roure, \& J.W. Granath). American Association of Petroleum Geologists Memoir, 391-411.

Grasso M. (2001) - The Apenninic/Maghrebian orogen in southern Italy, Sicily and adjacent areas. In: Anatomy of an Orogen: the Apennines and Adjacent Mediterranean Basins. (Ed by G.B. Vai, \& I.P. Martini), 255-286. Springer, Netherlands.

Grasso M. \& ButLER R.W.H. (1993) - Tectonic controls on the deposition of late Tortonian sediments in the Caltanissetta basin of central Sicily. Memorie della Società Geologica Italiana, 47, 313-324.

Grasso M. \& Pedley H.M. (1988) - The sedimentology and development of Terravecchia Formation carbonates (Upper Miocene) of North Central Sicily: possible eustatic influence on facies development. Sedimentary Geology, 57, 131-149.

Grasso M., Lentini F. \& Vezzani L. (1978) - Lineamenti stratigrafico strutturali delle Madonie (Sicilia centro-settentrionale). Geological Romana, 17, 45-69.

Grasso M., De Dominicis A. \& Mazzoldi G. (1990) - Structures and tectonic setting of the western margin of the Hyblean-Malta shelf, central Mediterranean. Annales Tectonicae, 4, 140-154.

Grasso M., Aiello A. \& Romeo M. (1999) - Età e posizione strutturale del "Flysch" di Reitano affiorante presso Cerami (Monti Nebrodi), Sicilia Centro-Settentrionale. Bolletino della Accademia Gioenia di Scienze Naturali Catania, 31, 211-223.

Grasso M., Lickorish W.H., Diliberto S.E., Geremia F., Maniscalco R., Maugeri S., Pappalardo G., Rapisarda F. \& Scamarda G. (1997) Geological map of the Licata fold belt (south-central Sicily). Società Elaborazioni Cartografiche, Firenze.

Graveleau F., Malavieille J. \& Dominguez S. (2012) - Experimental modelling of orogenic wedges: a review. Tectonophysics 538-540, 1-66.

Guerrera F., Martín-Algarra A. \& Martín Martín M. (2012) - Tectonosedimentary evolution of the "Numidian Formation" and Lateral Facies (southern branch of the western Tethys): Constraints for central-western Mediterranean geodynamics. Terra Nova, 24, 34-41.

Hatcher R.D. (1978) - Tectonics of the Western Piedmont and Blue Ridge southern Appalachians; review and speculation. American Journal of Science, 278, 276-404.

Higgins S., Clarke B., Davies R.J. \& Cartwright J. (2009) - Internal geometry and growth history of a thrust-related anticline in a deep water fold belt. Journal of Structural Geology 31, 1597-1611.

HudEC M.R. \& JACKSON M.P.A. (2009) -Interaction between spreading salt canopies and their peripheral thrust systems. Journal of Structura Geology, 31, 1114-1129.

Jones R.E. \& Grasso M. (1997) - Palaeotectonics and sediment dispersal pathways in north-central Sicily during the Late Tortonian. Studi Geologici Camerti, Volume Speciale, 2, 279-291.

Leggett J.K., McKerrow W.S. \& Eales M.H. (1979) - The Southern Uplands of Scotland: A Lower Palaeozoic accretionary prism. Journal of the Geological Society, London, 136, 755-770.

LENTINI F. (1974) - Caratteri stratigrafici e strutturali della zona di Mt. Judica (Sicilia Orientale). Rivista Mineraria Siciliana, 145-147, 1-22.

Lentini F. (1982) - The geology of the Mount Etna basement. In: Mount Etna volcano: a review of the recent earth sciences studies (Ed. By R. Romano) Memorie della Società Geologia Italiana. 23, 7-25.

Lentini F. (1984) - Carta Geologica della Siciulia Sud-Orientale. Società Elaborazioni Cartografiche, Firenze.

Lentini F. \& CARBone S. (2014) - Carta geologica della Sicilia (1:250,000). Società Elaborazioni Cartografiche, Firenze.
Lentini F., Carbone S., Catalano S. \& Grasso M. (1996) - Elementi per la ricostruzione del quadro strutturale della Sicilia Orientale. Memorie della Società Geologica Italiana, 51, 179-195.

Lickorish W.H. \& BUTLER R.W.H. (1996) - Fold amplification and parasequence stacking patterns in syn-tectonic shoreface carbonates. Bulletin of the Geological Society of America 108, 966-977.

Lickorish W.H., Grasso M., Butler R.W.H., Argnani A. \& Maniscalco R. (1999) - Structural styles and regional tectonic setting of the 'Gela Nappe' and frontal part of the Maghrebian thrust belt in Sicily. Tectonics, 18, 655-668.

Ogniben L. (1957) - Petrografia della Serie Sofifera Siciliana e considerazioni geologiche relative. Memorie Descrittive della Carta Geologica d'Italia, 22, pp 275.

Ogniben L. (1960) - Nota illustrativa dello schema geologico della Sicilia nord-orientale. Rivista Mineraria Sicilia, 11, 184-212.

OgNIBEN L. (1969) - Schema introduttivo alla geologia del confine calabrolucano. Memorie della Società Geologica Italiana, 8, 453-763.

Pedley H.M. \& Maniscalco R. (1999) - Lithofacies and faunal succession (faunal phase analysis) as a tool in unravelling climatic and tectonic signals in marginal basins; Messinian (Miocene), Sicily. Journal of the Geological Society, London, 156, 855-863.

Pinter P.R., Butler R.W.H., Hartley A.J., Maniscalco R., Baldassini N. \& Di STEFANo A. (2016) - The Numidian of Sicily revisited: a thrustinfluenced confined turbidite system. Marine and Petroleum Geology, 78, 291-311.

Pinter P.R., Butler R.W.H., Hartley A.J., Maniscalco R., Baldassini N. \& Di StEFano A. (2018) - Tracking sand fairways through a deformed turbidite system: the Numidian (Miocene) of Central-East Sicily, Italy. Basin Research, 30, 480-501.

Renda P., Tavarnelli E. \& Tramutoli M. (1999) - La distensione tetidea ed il suo controllo sulle strutture compressive del sistema appenninicomaghrebide: l'esempio dei Monti delle Madonie (Sicilia centrosettentrionale). Bolletino della Società Geologica Italiana 118 , 179-190.

Speranza F., Hernandez-Moreno C., Avellone G., Gasparo Morticelli M., Agate M., Sulli A. \& Di Stefano E. (2018) - Understanding paleomagnetic rotations in Sicily: Thrust versus strikeslip tectonics. Tectonics, 37, 1138-1158.

STORTI F. \& McCLAY K. (1995) - Influence of syntectonic sedimentation on thrust wedges in analogue models. Geology, 23, 999-1002.

Sturiale G., Maniscalco R., De Guidi G., Pedley H.M. \& Grasso M. (2010) - Carta geologica dei Bacini di Corvillo e Mandre (Sicilia centrale map, scale at 1:50.000). Società Elaborazioni Cartografiche, Firenze.

Tavarnelli E., Decandia A.F., Renda P., Tramutoli M., Gueguen E. \& Alberti M. (2001) - Repeated reactivation in the Apennine-Maghrebide system, Italy: a possible example of fault-zone weakening? Geological Society of London, Special Publications, 186, 273-286.

Totake Y., Butler R.W.H., Bond C.E. \& AzIz A. (2018) - Analyzing structural variations along strike in a deep-water thrust belt. Journal of Structural Geology, 108, 213-229.

Van Couvering J. A., Castradori D., Cita M. B., Hilgen F. J. \& Rio D. (2000) - The base of the Zanclean Stage and of the Pliocene Series. Episodes 23(3), 179 - 187.

Vitale S., Amore O.F., Ciarcia S., Fedele L., Grifa C., Prinzi E.P., Tavani S. \& D'Assissi Tramparulo F. (2018) - Structural, stratigraphic, and petrological clues for a Cretaceous-Paleogene abortive rift in the southern Adria domain (southern Apennines, Italy). Geological Journal 53, 660-681.

WiLliams G.D. (1993) - Tectonics and seismic sequence stratigraphy: an introduction. In: Tectonics and Seismic Sequence Stratigraphy (Ed. By G.D. Williams\& A. Dobb). Geological Society, London, Special Publications, 71, 1-13

Zarcone G., Petti F.M., Cillari A., Di Stefano P., Guzzetta D. \& Nicosia U. (2010) - A possible bridge between Adria and Africa: New palaeobiogeographic and stratigraphic constraints on the Mesozoic palaeogeography of the Central Mediterranean area. Earth-Science Review, 103, 154-162. 